\title{
Mortality among patients with ankylosing spondylitis after a single treatment course with $x$ rays
}

\author{
P G SMITH, RICHARD DOLL
}

\begin{abstract}
Mortality was studied in 14111 patients with ankylosing spondylitis given a single course of $x$-ray treatment during 1935-54. Mortality from all causes combined was $66 \%$ greater than that of members of the general population of England and Wales. There were substantial excesses of deaths from non-neoplastic conditions, but these appeared to be associated with the disease itself rather than its treatment. A nearly fivefold excess of deaths from leukaemia and a $62 \%$ excess of deaths from cancers of sites that would have been in the radiation fields ("heavily irradiated sites") were likely to have been a direct consequence of the radiation treatment itself. The excess death rate from leukaemia was greatest three to five years after treatment and was close to zero after 18 years. In contrast, the excess of cancers of heavily irradiated sites did not become apparent until nine or more years after irradiation and continued for a further 11 years. More than 20 years after irradiation the excess risk declined, but the fall was not statistically significant. The number of cancers of sites not considered to be in the radiation beams was $20 \%$ greater than expected. This excess, although not statistically significant, may also have been due to radiation scattered from beams directed at other parts of the body.

The risk of a radiation-induced leukaemia or other cancer was related to the age of the patient at the time of treatment. Those irradiated when aged 55 years or more had an excess death rate from leukaemia more than 15 times that of those treated under 25 years of age, and a similar difference was apparent for cancers of heavily irradiated sites. The radiation dose to the bone marrow was estimated for the patients who died with leukaemia
\end{abstract}

\footnotetext{
Department of Medical Statistics and Epidemiology, London School of Hygiene and Tropical Medicine, London WC1E 7HT

P G SMITH, BSC, senior lecturer in tropical epidemiology

ICRF Cancer Epidemiology and Clinical Trials Unit, Department of Community Medicine and General Practice, University of Oxford, Radcliffe Infirmary, Oxford OX2 6HE

SIR RICHARD DOLL, MD, FRCP, FRS, honorary director
}

and for a 1 in 15 sample of the total study population. The excess risk of leukaemia varied erratically with radiation dose owing, perhaps, in part to the increase in the proportion of the cells in the bone marrow that are sterilised with increasing doses. A mathematical model using a linear leukaemia induction rate and exponential cell sterilisation fitted the data reasonably well, and the results suggested that for low radiation doses about two deaths from leukaemia would be induced per million people per rad of $x$ rays per year for up to 20 years after exposure. Because of the failure to find a clear doseresponse relationship this estimate must be regarded with caution, but it is in reasonable agreement with that derived from studies of the atomic bomb survivors.

\section{Introduction}

Court Brown and Doll identified over 14000 patients with ankylosing spondylitis who had been treated with one or more courses of $x$ irradiation from 1935 to 1954 at one of 87 radiotherapy centres in Great Britain and Northern Ireland. Previous reports have analysed mortality among these patients from leukaemia ${ }^{1}$ and other causes, particularly cancer ${ }^{2}$ but these analyses included many patients who had been treated with $x$ rays for their spondylitis more than once. This complicated the interpretation of the late effects of the treatment on mortality as it was not clear to what extent the subsequent treatments contributed to the excess of deaths that persisted for many years after the first treatment. We have avoided this difficulty by examining the death rate from leukaemia and other radiationinduced cancers at different times after a single course of treatment.

\section{Methods}

STUDY POPULATION AND FOLLOW-UP

A total of $14560^{*}$ patients were included in the study (table I). Of these we excluded 406 who were entered into the study at the date of

* 14554 patients were included in the previous report. ${ }^{2}$ One patient was found to have been included twice and seven to have been omitted from the previous analysis. 
their second or later radiation treatment course and 43 whose date of birth or age at first treatment was unknown. All except $208(1.5 \%)$ of the remaining 14111 patients were traced to their death, date of emigration from the United Kingdom, 1 January 1970, or the end of the year after their second treatment course, whichever was the earliest. Retreated patients were traced for on average 18 months beyond their second course (to the end of the year after the one in which they were retreated). Any leukaemias or cancers induced by the second course of radiation treatment were unlikely to have appeared and caused death in this short interval. Some patients may, however, have received a second course as a result of the early symptoms of a cancer being misdiagnosed as reactivated spondylitis and treated accordingly, and failure to have followed them beyond the date of the second treatment course might have led us to underestimate the number of radiation-induced tumours associated with the original radiation treatment.

Over half of the patients were retreated before 1 January 1970, 1759 patients had died, and 269 had emigrated. The remaining 4420, who received only one course of treatment, were alive and living in the United Kingdom on 1 January 1970 (table I). The average follow-up months. The numbers of deaths expected by cause were estimated by multiplying the person-years at risk by the corresponding age- and sex-specific mortality rates for England and Wales. Cancer death rates $c$ were taken from the tables published by Case et $a l^{4}$ and by the Office of Population Censuses and Surveys, ${ }^{5}$ and death rates for other causes were compiled from the annual reports of the Registrar General for England and Wales.

All death rates were based on the 7th revision of the ICD. For 6 years in which the Registrar General had used revisions other than the 7th the equivalent classifications were calculated from the published data. The number of years at risk were calculated separately for men and women for each five-year age group and for 1935-40, for each quinquennium from 1941-5 to 1961-5, and for 1966-9. Differences between the actual number of deaths from each cause and the number expected were tested for statistical significance by calculating the probability of obtaining a value greater than or equal to the number observed if sampling from a Poisson distribution with a mean equal to the expected number of deaths-that is, one-sided tests were performed. Tests for trends were performed using the method described by Mantel $^{6}$ and were two-sided tests.

TABLE I-Definition of study population. Results are numbers (and percentages) of patients

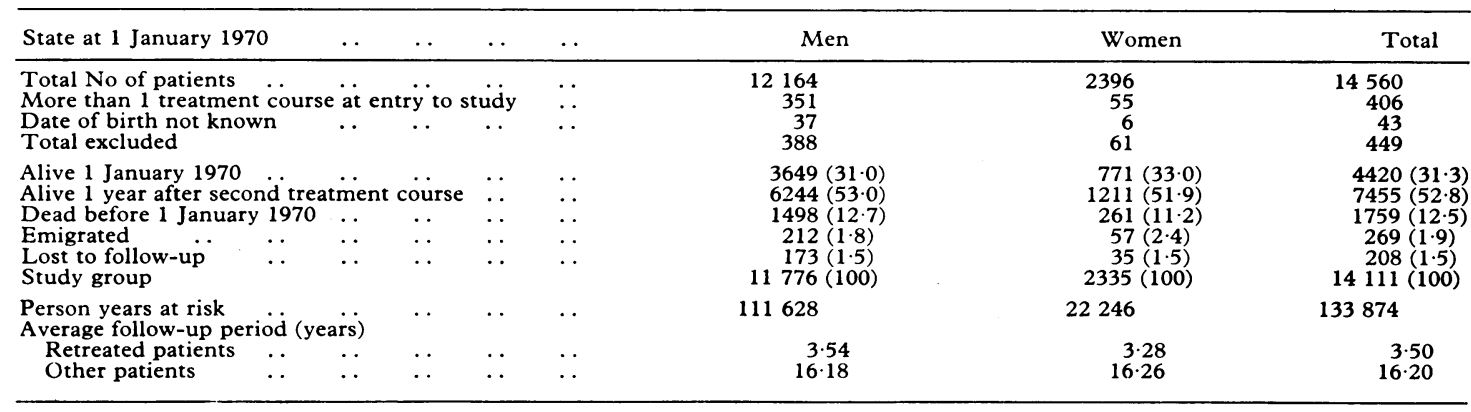

TABLE II-Sample of patients for whom estimates were made of bone marrow radiation dose for first course of treatment

\begin{tabular}{lccccc}
\hline $\begin{array}{c}\text { Amount of treatment } \\
\text { group (sampling class) }\end{array}$ & $\begin{array}{c}\text { No of patients } \\
\text { in sample }\end{array}$ & Exclusions* & $\begin{array}{c}\text { Insufficient } \\
\text { data }\end{array}$ & $\begin{array}{c}\text { No of patients with } \\
\text { bone marrow dose } \\
\text { estimated }\end{array}$ & $\begin{array}{c}\text { Mean marrow dose } \\
\text { in rads (SD) }\end{array}$ \\
\hline (1) One course & 509 & 1 & 10 & 498 & $347(181)$ \\
(2) Two courses & 195 & 2 & 4 & 189 & $298(192)$ \\
(3) Three courses & 87 & 1 & 0 & 86 & $309(188)$ \\
(4) Four or more courses & 85 & 0 & 10 & 55 & $302(175)$ \\
(5) Treatment at two or & 87 & 24 & 8 & 903 & $321(185)$ \\
more centres & 963 & 28 & 32 & 55 & $(158)$ \\
\hline Total & 963 &
\end{tabular}

* Date of birth not known (3); entered study with previous treatment (25).

was $16 \cdot 2$ years for patients who had only one course of treatment and 3.5 years for those who were retreated.

For patients who had died the causes of death were obtained from death certificates, and the primary cause was coded according to the 7th revision of the International Classification of Diseases, Injury and Causes of Death. ${ }^{3}$ Death certificates were not obtained for five patients who had died while temporarily abroad: one died in a motor accident, and another death was ascribed to coronary thrombosis after necropsy; the causes of death of the other three could not be ascertained.

\section{COMPUTATION OF EXPECTED NUMBER OF DEATHS}

Person-years at risk were computed by assuming each patient to have entered the study in the middle of the year of first treatment and to have left in the middle of the year of death or emigration, at the end of the year after the second course of treatment, or on 1 January 1970. (Only the years of birth, treatment, emigration, loss to follow-up and death were recorded on the computer file. Thus these events were assumed to have occurred in the middle of the recorded year.) Patients who emigrated, died, or were lost in the same year as that of the first treatment course were assumed to have been at risk for three

\section{RADIATION DOSIMETRY}

\section{Bone marrow}

For the 1957 report, estimates of the mean radiation dose to the $\frac{D}{D}$ spinal bone marrow and of the whole body integral dose were derived for a sample of approximately one in six of the patients in the original $\widetilde{O}$ series. The sample of one in six patients was selected separately for $N$ each centre for each year in which treatment was started, and different sampling fractions were used for each of the five "amount of treatment" classes. The allocation of a patient to a class depended on whether he or she had had 1,2, 3, 4 or more courses of treatment (classes 1 to 4 ) or had been treated at two or more centres (class 5). For patients receiving only one treatment course a 1 in 15 sample was selected, but larger sampling fractions were used in the groups receiving two or more courses of radiation as there were fewer patients in these groups and the more heavily treated patients were of greatest interest. In the 1957 report $^{1}$ radiation doses from different treatment courses were added together to derive an overall dose for each sampled patient. In this analysis we were concerned only with the dose from the first or only course of treatment. There was no reason to emphasise the dosage estimation for patients treated more than once, so we selected patients at random, within each treatment centre, from 
the patients who had been included in sampling classes 2 to 5 , so as to obtain a 1 in 15 sample of patients from each class. The numbers of patients included in the final sample from each class are shown in table II.

For each sampled patient information was sought from the radiotherapy notes on the size and location of each radiation field used in the first course of treatment, the skin dose of radiation to each field, the focal skin distance used, the filtration used, and the voltage of the $x$-ray machine. From these data we derived an estimate, for each sampled patient, of the mean radiation dose to the bone marrow using a computer program which incorporated the results of extensive dose measurements on a phantom.?

Of the 963 patients in the sample (table II) 28 were excluded because either their date of birth was not known (three patients) or they had entered the study having had previous treatment for ankylosing spondylitis. Both of these categories of patients had already been excluded from the main study. The 935 patients left in the sample representing a 1 in 15.09 sample of the whole study group. Mean bone marrow dose estimates could be made for $903(96.6 \%)$ of these patients.

\section{Other organs}

To obtain estimates of the doses to organs other than the bone marrow, Professor R Ellis and Dr N Lewis sought to adapt the computer program developed by Rosenstein ${ }^{8}$ so that it would use our data. Professor Ellis's sudden death, however, prevented the analysis from being completed and, temporarily, we have used the estimates provided by the Advisory Committee on the Biological Effects of Ionising Radiations (BEIR committee). ${ }^{9}$

\section{Results}

MORTALITY COMPARED TO THAT OF THE GENERAL POPULATION All causes

A total of 1759 deaths occurred in the study group whereas only 1061.6 were expected from age- and sex-specific death rates in the general population of England and Wales for the corresponding calendar years (table III). This $66 \%$ excess of deaths was statistically highly significant, as was the excess from all neoplasms and from all other causes (in each case $p<0 \cdot 001$ ). The size of these excesses was similar in men and women, and the differences in the ratios of observed to expected deaths between the sexes were not statistically significant. Women made up only $16.5 \%$ of the study population and, as the findings among women were similar to those for men, the two sexes were considered together in most of the subsequent analyses.

\section{Neoplastic diseases}

Following the procedure adopted by Court Brown and Doll ${ }^{2}$ we divided deaths from neoplastic diseases into four categories, as follows: (a) leukaemia, which was considered separately because of the very different effects of $x$ irradiation on subsequent mortality from this cause compared with those on other neoplastic diseases; (b) cancer of the colon, which may be associated with spondylitis through the increased risk of ulcerative colitis among spondylitics; (c) cancers of "lightly irradiated" sites-that is, sites which were not likely to have been included directly in radiation beams with standard treatment and would have received only a minimal dose of radiation through scatter

TABLE III-Observed and expected deaths by cause

\begin{tabular}{|c|c|c|c|c|c|c|c|c|c|c|c|c|c|c|}
\hline & & & & & & \multicolumn{3}{|c|}{ Men } & \multicolumn{3}{|c|}{ Women } & \multicolumn{3}{|c|}{ Total } \\
\hline & & & & & & Observed & Expected & $\mathrm{O} / \mathrm{E}$ & Observed & Expected & $\mathbf{O} / \mathbf{E}$ & Observed & Expected & $\mathrm{O} / \mathrm{E}$ \\
\hline $\begin{array}{l}\text { All causes } \ldots \\
\text { All neoplasms }\end{array}$ & $\begin{array}{l}\cdots \\
\cdots\end{array}$ & $\begin{array}{l}\cdots \\
\cdots\end{array}$ & $\begin{array}{l}\cdots \\
\cdots\end{array}$ & . & $\begin{array}{l}\ldots \\
\cdots\end{array}$ & $\begin{array}{r}1498^{* * * *} \\
339^{* * *}\end{array}$ & $\begin{array}{l}900 \cdot 25 \\
214 \cdot 19\end{array}$ & $\begin{array}{l}1.66 \\
1.58\end{array}$ & $\begin{array}{l}261^{* * * *} \\
58^{*}\end{array}$ & $\begin{array}{r}161 \cdot 36 \\
42 \cdot 73\end{array}$ & $\begin{array}{l}1.62 \\
1.36\end{array}$ & $\begin{array}{r}1759 * * * \\
397 * * *\end{array}$ & $\begin{array}{r}1061 \cdot 61 \\
256.92\end{array}$ & $\begin{array}{l}1.66 \\
1.55\end{array}$ \\
\hline $\begin{array}{l}\text { Leukaemia } \\
\text { Carcinoma of colo } \\
\text { Carcinoma in heav } \\
\text { Carcinoma in ligh }\end{array}$ & $\begin{array}{l}\text { a } \\
\text { ily irrad } \\
\text { ly irradi }\end{array}$ & $\begin{array}{l}\ldots \\
\text { diated } s \\
\text { liated } s i\end{array}$ & $\begin{array}{l}\ldots \\
\text { sites } \\
\text { ites }\end{array}$ & $\begin{array}{l}\cdots \\
\cdots \\
\cdots\end{array}$ & $\begin{array}{l}\cdots \\
\because \\
\cdots\end{array}$ & $\begin{array}{l}28^{* * * *} \\
23^{* *} \\
234^{* * *} \\
54\end{array}$ & $\begin{array}{r}5.49 \\
13.17 \\
149.98 \\
45.56\end{array}$ & $\begin{array}{l}5 \cdot 10 \\
1.75 \\
1.56 \\
1.19\end{array}$ & $\begin{array}{r}3 \\
5 \\
25 \\
25\end{array}$ & $\begin{array}{r}0.98 \\
4 \cdot 12 \\
17.53 \\
20 \cdot 09\end{array}$ & $\begin{array}{l}3.06 \\
1.21 \\
1.43 \\
1.24\end{array}$ & $\begin{array}{l}31^{* * *} \\
28^{*} \\
259^{* * *} \\
79\end{array}$ & $\begin{array}{r}6.47 \\
17.30 \\
167.50 \\
65.65\end{array}$ & $\begin{array}{l}4.79 \\
1.62 \\
1.55 \\
1.20\end{array}$ \\
\hline All other causes & .. & . & . & . & .. & $1159 * * *$ & $686 \cdot 06$ & 1.69 & $203 * * *$ & 118.62 & $1 \cdot 71$ & $1362^{* * *}$ & $804 \cdot 68$ & 1.69 \\
\hline
\end{tabular}

*0.01<p<0.05; ** $0.001<\mathrm{p}<0.01 ;{ }^{* * *} \mathrm{p}<0.001$.

\begin{tabular}{|c|c|c|c|c|c|c|c|c|c|c|c|c|c|c|c|}
\hline & & & & & \multicolumn{10}{|c|}{ Time since treatment (years) } & \multirow[b]{2}{*}{ Total } \\
\hline & & & & & $0-2^{*}$ & $3-5$ & $6-8$ & $9-11$ & $12-14$ & $15-17$ & $18-20$ & $21-23$ & $24-26$ & $\geqslant 27$ & \\
\hline $\begin{array}{ll}\text { All causes } & \\
\text { Observed } & \ldots \\
\text { Expected } & \ldots \\
\text { O/E } & \ldots\end{array}$ & $\begin{array}{l}\cdots \\
\cdots\end{array}$ & $\begin{array}{l}. \\
\cdots \\
\cdots\end{array}$ & $\begin{array}{l}. \\
\cdots\end{array}$ & $\begin{array}{l}\cdots \\
\cdots\end{array}$ & $\begin{array}{l}274 \\
157.43 \\
1.74\end{array}$ & $\begin{array}{r}254 \\
134.14 \\
1.89\end{array}$ & $\begin{array}{r}216 \\
131.44 \\
1.64\end{array}$ & $\begin{array}{l}253 \\
143.89 \\
1.76\end{array}$ & $\begin{array}{l}253 \\
159 \cdot 46 \\
1.59\end{array}$ & $\begin{array}{l}227 \\
157.21 \\
1.44\end{array}$ & $\begin{array}{l}153 \\
100 \cdot 27 \\
1.53\end{array}$ & $\begin{array}{l}83 \\
50.18 \\
1.65\end{array}$ & $\begin{array}{l}37 \\
19.90 \\
1.86\end{array}$ & $\begin{array}{l}9 \\
7.69 \\
1.17\end{array}$ & $\begin{array}{r}1759 \\
1061.61 \\
1.66\end{array}$ \\
\hline $\begin{array}{c}\text { All neoplasms } \\
\text { Observed } \\
\text { Expected } \\
\text { O/E }\end{array}$ & $\begin{array}{l}\cdots \\
\cdots \\
\cdots\end{array}$ & $\begin{array}{l}\cdots \\
\cdots\end{array}$ & $\begin{array}{l}\cdots \\
\cdots\end{array}$ & $\begin{array}{l}\ldots \\
\cdots\end{array}$ & $\begin{array}{l}56 \\
32 \cdot 81 \\
1.71\end{array}$ & $\begin{array}{r}52 \\
31.04 \\
1.68\end{array}$ & $\begin{array}{l}41 \\
32 \cdot 28 \\
1 \cdot 27\end{array}$ & $\begin{array}{r}62 \\
35.98 \\
1.72\end{array}$ & $\begin{array}{r}66 \\
40.33 \\
1.64\end{array}$ & $\begin{array}{l}58 \\
39 \cdot 80 \\
1.46\end{array}$ & $\begin{array}{r}40 \\
25.36 \\
1.58\end{array}$ & $\begin{array}{l}14 \\
12 \cdot 52 \\
1 \cdot 12\end{array}$ & $\begin{array}{l}5 \\
4.98 \\
1.00\end{array}$ & $\begin{array}{l}3 \\
1.81 \\
1.66\end{array}$ & $\begin{array}{r}397 \\
256.92 \\
1.55\end{array}$ \\
\hline $\begin{array}{cc}\text { Leukaemia } & \\
\text { Observed } & \ldots \\
\text { Expected } & \ldots \\
\text { O/E } & \ldots\end{array}$ & $\begin{array}{l}\ldots \\
\cdots\end{array}$ & $\begin{array}{l}\cdots \\
\cdots\end{array}$ & $\begin{array}{l}. \\
\cdots\end{array}$ & $\begin{array}{l}\ldots \\
\cdots\end{array}$ & $\begin{array}{l}6 \\
1.00 \\
6.00\end{array}$ & $\begin{array}{l}10 \\
0.89 \\
11 \cdot 24\end{array}$ & $\begin{array}{l}6 \\
0 \cdot 87 \\
6.90\end{array}$ & $\begin{array}{l}3 \\
0.90 \\
3.33\end{array}$ & $\begin{array}{l}1 \\
0.96 \\
1.04\end{array}$ & $\begin{array}{l}4 \\
0 \cdot 90 \\
4 \cdot 44\end{array}$ & $\begin{array}{l}1 \\
0.55 \\
1.82\end{array}$ & $\begin{array}{l}0 \\
0 \cdot 26 \\
0.00\end{array}$ & $\begin{array}{l}0 \\
0 \cdot 10 \\
0.00\end{array}$ & $\begin{array}{l}0 \\
0.04 \\
0.00\end{array}$ & $\begin{array}{l}31 \\
6.47 \\
4.79\end{array}$ \\
\hline $\begin{array}{c}\text { Carcinoma of } \\
\text { Observed } \\
\text { Expected } \\
\text { O/E }\end{array}$ & $\begin{array}{l}\ldots \\
\cdots\end{array}$ & $\begin{array}{l}\cdots \\
\therefore\end{array}$ & $\begin{array}{l}\cdots \\
\cdots\end{array}$ & $\begin{array}{l}. \\
. \\
.\end{array}$ & $\begin{array}{l}6 \\
2 \cdot 52 \\
2 \cdot 38\end{array}$ & $\begin{array}{l}4 \\
2 \cdot 22 \\
1 \cdot 80\end{array}$ & $\begin{array}{l}2 \\
2.17 \\
0.92\end{array}$ & $\begin{array}{l}5 \\
2 \cdot 34 \\
2 \cdot 14\end{array}$ & $\begin{array}{l}4 \\
2.58 \\
1.55\end{array}$ & $\begin{array}{l}3 \\
2.56 \\
1 \cdot 17\end{array}$ & $\begin{array}{l}3 \\
1.64 \\
1.83\end{array}$ & $\begin{array}{l}0 \\
0 \cdot 81 \\
0.00\end{array}$ & $\begin{array}{l}0 \\
0.32 \\
0.00\end{array}$ & $\begin{array}{l}1 \\
0 \cdot 12 \\
8 \cdot 33\end{array}$ & $\begin{array}{l}28 \\
17 \cdot 30 \\
1.62\end{array}$ \\
\hline $\begin{array}{c}\text { Carcinoma in } \mathrm{h} \\
\text { Observed } \\
\text { Expected } \\
\text { O/E }\end{array}$ & $\begin{array}{l}\text { ily i } \\
\ldots \\
\cdots \\
\cdots\end{array}$ & $\begin{array}{c}\text { diate } \\
\cdots \\
\cdots\end{array}$ & $\begin{array}{c}\text { ites } \\
\cdots \\
\cdots\end{array}$ & $\begin{array}{l}. . \\
\therefore\end{array}$ & $\begin{array}{l}33 \\
19.91 \\
1.66\end{array}$ & $\begin{array}{r}27 \\
19.48 \\
1.39\end{array}$ & $\begin{array}{l}24 \\
20.83 \\
1.15\end{array}$ & $\begin{array}{l}45 \\
23.61 \\
1.91\end{array}$ & $\begin{array}{l}46 \\
26 \cdot 81 \\
1 \cdot 72\end{array}$ & $\begin{array}{l}43 \\
26.64 \\
1.61\end{array}$ & $\begin{array}{l}26 \\
17.06 \\
1.52\end{array}$ & $\begin{array}{r}11 \\
8.51 \\
1.29\end{array}$ & $\begin{array}{l}3 \\
3.44 \\
0.87\end{array}$ & $\begin{array}{l}1 \\
1.22 \\
0.82\end{array}$ & $\begin{array}{r}259 \\
167.50 \\
1.55\end{array}$ \\
\hline $\begin{array}{cc}\text { Carcinoma in li } \\
\text { Observed } \\
\text { Expected } \\
\text { O/E }\end{array}$ & $\begin{array}{l}\text { ly ir } \\
\ldots \\
\cdots \\
\cdots\end{array}$ & $\begin{array}{l}\text { iate } \\
\ldots \\
\cdots \\
\ldots\end{array}$ & $\begin{array}{l}\text { ites } \\
\because \\
\cdots \\
\therefore\end{array}$ & $\begin{array}{l}. \\
\cdots\end{array}$ & $\begin{array}{r}11 \\
9.38 \\
1 \cdot 17\end{array}$ & $\begin{array}{r}11 \\
8.45 \\
1.30\end{array}$ & $\begin{array}{l}9 \\
8.41 \\
1.07\end{array}$ & $\begin{array}{l}9 \\
9 \cdot 13 \\
0.99\end{array}$ & $\begin{array}{r}15 \\
9.98 \\
1.50\end{array}$ & $\begin{array}{l}8 \\
9 \cdot 70 \\
0.82\end{array}$ & $\begin{array}{l}10 \\
6 \cdot 10 \\
1.64\end{array}$ & $\begin{array}{l}3 \\
2.94 \\
1.02\end{array}$ & $\begin{array}{l}2 \\
1.13 \\
1 \cdot 77\end{array}$ & $\begin{array}{l}1 \\
0 \cdot 43 \\
2 \cdot 33\end{array}$ & $\begin{array}{l}79 \\
65.65 \\
1.20\end{array}$ \\
\hline $\begin{array}{c}\text { All other causes } \\
\text { Observed } \\
\text { Expected } \\
\text { O/E }\end{array}$ & $\begin{array}{l}\cdots \\
\cdots\end{array}$ & $\begin{array}{l}\cdots \\
\cdots\end{array}$ & $\begin{array}{l}\because \\
\cdots\end{array}$ & $\begin{array}{l}\cdots \\
\cdots\end{array}$ & $\begin{array}{r}218 \\
124 \cdot 62 \\
1.75\end{array}$ & $\begin{array}{r}202 \\
103.10 \\
1.96\end{array}$ & $\begin{array}{r}175 \\
99 \cdot 15 \\
1.77\end{array}$ & $\begin{array}{r}191 \\
107.91 \\
1.77\end{array}$ & $\begin{array}{l}187 \\
119.13 \\
1.57\end{array}$ & $\begin{array}{r}169 \\
117.42 \\
1.44\end{array}$ & $\begin{array}{r}113 \\
74.91 \\
1.51\end{array}$ & $\begin{array}{l}69 \\
37.66 \\
1.83\end{array}$ & $\begin{array}{r}32 \\
14.92 \\
2 \cdot 14\end{array}$ & $\begin{array}{l}6 \\
5.88 \\
1.02\end{array}$ & $\begin{array}{r}1362 \\
804.68 \\
1.69\end{array}$ \\
\hline Years at risk & .. & .. & .. & $\ldots$ & 32434 & 23956 & 19480 & 17296 & 15851 & 12961 & 7232 & 3196 & 1125 & 343 & 133874 \\
\hline
\end{tabular}

* Patients were considered to have left this interval at the end of the second year after the year of first treatment. As only the year of first treatment was recorded; on average patients would have left the interval after $2 \frac{1}{2}$ years (for individual patients the minimal time spent in the interval could have been 2 years (if they had been first treated at the end of December) and the maximal time 3 years (if they were treated at the start
periods corresponding, on average, to $2 \frac{1}{2}$ to $5 \frac{1}{2}$ years, $5 \frac{1}{2}$ to $8 \frac{1}{2}$ years, etc. 
TABLE V-Excess risk of death from cancers of heavily irradiated sites and from or with leukaemia by time since first treatment

\begin{tabular}{|c|c|c|c|c|c|c|c|c|c|c|c|c|}
\hline & \multicolumn{10}{|c|}{ Time since first treatment (years) } & \multirow{2}{*}{\multicolumn{2}{|c|}{ Total $[\geqslant 2]$}} \\
\hline & $0-2 \ddagger$ & {$[2] ! !$} & $3-5$ & $6-8$ & $9-11$ & $12-14$ & $15-17$ & $18-20$ & $21-23$ & $\geqslant 24$ & & \\
\hline \multirow{2}{*}{$\begin{array}{l}\text { Person years at risk } \\
\text { Excess death rates (per } 10^{5} / \text { year) } \\
\text { Cancers of heavily irradiated } \\
\text { sites }\end{array}$} & 32434 & {$\left[\begin{array}{ll}11 & 520\end{array}\right]$} & 23956 & 19480 & 17296 & 15851 & 12961 & 7232 & 3196 & 1468 & 133874 & {$[112960]$} \\
\hline & $40 \cdot 3$ & & $31 \cdot 4$ & $16 \cdot 3$ & $123 \cdot 7$ & $121 \cdot 1$ & $126 \cdot 2$ & $123 \cdot 6$ & $78 \cdot 0$ & $-44 \cdot 5$ & 68 . & \\
\hline \multirow{2}{*}{$\begin{array}{l}\text { Leukaemia* } \\
\text { No of deaths with leukaemia } \dagger \\
\text { Observed } \\
\text { Expected } \\
\text { O/E } \\
\text { Excess death rate }\end{array}$} & $15 \cdot 4 \S$ & & $38 \cdot 0$ & $26 \cdot 3$ & $12 \cdot 1$ & 0.3 & 23.9 & & $0 \cdot 4$ & & 18 . & 3 \\
\hline & & $\begin{array}{c}{[4(1)]} \\
{[0.47]} \\
{[8.5]} \\
{[30.6]}\end{array}$ & $\begin{array}{c}12(2) \\
1 \cdot 12 \\
10 \cdot 7 \\
45 \cdot 4\end{array}$ & $\begin{array}{c}7(1) \\
1.09 \\
6.4 \\
30.3\end{array}$ & $\begin{array}{c}4(1) \\
1 \cdot 13 \\
3.5 \\
16.6\end{array}$ & $\begin{array}{l}2(1) \\
1 \cdot 20 \\
1.7 \\
5 \cdot 0\end{array}$ & $\begin{array}{c}5(1) \\
1.12 \\
4.5 \\
29.9\end{array}$ & & $\begin{array}{c}1 \\
1.19 \\
0.8 \\
-1.6\end{array}$ & & & $\begin{array}{c}{[35(7)]} \\
{[7.31]} \\
{[4 \cdot 8]} \\
{[24.5]}\end{array}$ \\
\hline
\end{tabular}

* Only patients whose primary cause of death was recorded as leukaemia are included.

+ Seven patients with leukaemia whose primary cause of death was not recorded as leukaemia are included in the figures and are also shown in parentheses.

See footnote to table IV.

$\$$ If the three patients whose leukaemia is believed to have led to the treatment are omitted the excess death rate reduces to $6 \cdot 17 / 10^{5} / \mathrm{year}$

Second year after year of first treatment.

TABLE VI-Observed and expected deaths from cancers of lightly irradiated sites

\begin{tabular}{|c|c|c|c|c|c|c|c|c|c|c|c|c|c|c|}
\hline \multirow[b]{3}{*}{ Site† } & & & & & & \multicolumn{6}{|c|}{ Time since first treatment (years) } & & & \\
\hline & & & & & & \multicolumn{3}{|c|}{$0-2$} & \multicolumn{3}{|c|}{$\geqslant 3$} & \multicolumn{3}{|c|}{ Total } \\
\hline & & & & & & Observed & Expected & $\mathbf{O} / \mathbf{E}$ & Observed & Expected & $\mathrm{O} / \mathrm{E}$ & Observed & Expected & $\mathbf{O} / \mathbf{E}$ \\
\hline $\begin{array}{l}\text { Brain } \ldots \\
\text { Mouth .. } \\
\text { Tongue } \\
\text { Liver and g } \\
\text { Rectum } \\
\text { Breast .. } \\
\text { Uterus .. } \\
\text { Prostate } \\
\text { Testes .. } \\
\text { Kidney } \\
\text { Bladder } \\
\text { Other sites }\end{array}$ & $\begin{array}{l}\ldots \\
\because \\
\text { bladder } \\
\ldots \\
\because \\
\cdots \\
\cdots \\
\therefore \\
\cdots\end{array}$ & $\begin{array}{l}\ldots \\
\cdots \\
\mathrm{r} \\
\ldots \\
\cdots \\
\cdots \\
\therefore \\
\cdots \\
\cdots\end{array}$ & $\begin{array}{l}. \\
\cdots \\
\because \\
\because \\
\because \\
\cdots \\
\cdots \\
\cdots\end{array}$ & $\begin{array}{l}\ldots \\
\cdots \\
\cdots \\
\cdots \\
\cdots \\
\cdots \\
\cdots \\
\cdots\end{array}$ & $\begin{array}{l}\ldots \\
\ldots \\
\ldots \\
\therefore \\
\cdots \\
\cdots \\
\cdots \\
\cdots \\
\cdots\end{array}$ & $\begin{array}{l}2 \\
0 \\
0 \\
1 \\
1 \\
1 \\
0 \\
3^{*} \\
1 \\
1 \\
0 \\
1 \\
\end{array}$ & $\begin{array}{l}1.66 \\
0.15 \\
0.18 \\
0.69 \\
1.86 \\
1.42 \\
0.71 \\
0.72 \\
0.35 \\
0.50 \\
0.84 \\
0.32\end{array}$ & $\begin{array}{l}1.20 \\
0.00 \\
0.00 \\
1.45 \\
0.54 \\
0.70 \\
0.00 \\
4.17 \\
2.86 \\
2.00 \\
0.00 \\
3.13\end{array}$ & $\begin{array}{r}10 \\
2 \\
0 \\
1 \\
13 \\
14 \\
4 \\
6 \\
0 \\
7 \\
11 \\
0\end{array}$ & $\begin{array}{r}7.98 \\
0.90 \\
0.82 \\
4.15 \\
10.55 \\
8.67 \\
3.68 \\
6.38 \\
1.02 \\
3.59 \\
6.82 \\
1.68\end{array}$ & $\begin{array}{l}1.25 \\
2.22 \\
0.00 \\
0.24 \\
1.23 \\
1.61 \\
1.09 \\
0.94 \\
0.00 \\
1.95 \\
1.61 \\
0.00\end{array}$ & $\begin{array}{r}12 \\
2 \\
0 \\
2 \\
14 \\
15 \\
4 \\
9 \\
1 \\
8 \\
11 \\
1\end{array}$ & $\begin{array}{r}9 \cdot 64 \\
1.06 \\
1.00 \\
4 \cdot 85 \\
12 \cdot 41 \\
10 \cdot 09 \\
4 \cdot 39 \\
7 \cdot 10 \\
1.37 \\
4.09 \\
7.66 \\
2.00\end{array}$ & $\begin{array}{l}1.24 \\
1.89 \\
0.00 \\
0.41 \\
1.13 \\
1.49 \\
0.91 \\
1.27 \\
0.73 \\
1.96 \\
1.44 \\
0.50\end{array}$ \\
\hline Total & .. & .. & .. & .. & .. & 11 & $9 \cdot 38$ & $1 \cdot 17$ & 68 & $56 \cdot 26$ & $1 \cdot 21$ & 79 & $65 \cdot 65$ & $1 \cdot 20$ \\
\hline
\end{tabular}

$* \mathrm{p}<0.05$.

$+\mathrm{I} C D(7)$ codes are as follows: brain $(193,223,237$, excluding tumours of the spinal cord and nerves), mouth $(143,144,145 \cdot 0) ;$ tongue $(141) ;$ liver $(155,156) ;$ rectum $(154) ;$ breast (170); uterus $(171-174)$; prostate (177); testes $(178)$; kidney $(180,195 \cdot 0)$; bladder $(181)$. Other lightly irradiated sites: lip (140); vulva and vagina (176.0, 176.1); penis and scrotum $(179 \cdot 0,179 \cdot 1)$; jaw $(196 \cdot 0,196 \cdot 1)$; nose $(160)$.

from beams directed at other parts of the body (see table VI). Most of these sites are the same as those given by Court Brown and Doll ${ }^{2}$ except for the spinal cord and nerves, which we have classified separately as "heavily irradiated," and the mouth, lip, vulva, vagina, penis, scrotum, jaw, and nose, which we have included with the lightly irradiated sites. The radiation fields used to treat some patients probably included some of the "lightly irradiated" sites directly in the radiation beams and it may be necessary to revise the classification of some when reliable estimates of organ doses have been made; $(d)$ cancers of "heavily irradiated" sites which are thought most likely to have been directly in treatment beams (see table VII); these sites were obtained by subtracting the three preceding categories from all neoplasms (ICD 7 140-239).

Leukaemia-There was an almost fivefold excess of deaths from leukaemia compared with the number expected from mortality rates for England and Wales (table III). Table IV shows the observed and expected numbers of deaths from leukaemia at different intervals after the first treatment course. The greatest excess in terms of either the ratio of observed to expected deaths or the excess death rate per 100000 person years at risk (table V) occurred in the period from three to five years (on average $2 \frac{1}{2}$ to $5 \frac{1}{2}$ years, see footnote to table IV) after the first treatment. (The excess death rate was calculated by subtracting the expected number of deaths in an interval from the number actually observed and dividing this by the total person-years at risk in the interval.) There was a statistically significant decline in the ratio of observed to expected deaths from 3 to 5 years after treatment to 18 years and more after treatment (table IV, $\chi^{2}(1 \mathrm{df}$ trend) $=10.40$; $\mathrm{p}<0.01$ ) and also in the excess death rate from leukaemia over the same period (table $\mathrm{V}: \chi^{2}(1 \mathrm{df}$ trend) $=4.94 ; \mathrm{p}<0.05)$. Three of the deaths from leukaemia occurred in the same year as the first treatment, and the leukaemia is thought to have been the cause of the symptoms which led to the treatment. ${ }^{1}$ These deaths were excluded from subsequent analyses, and the expected number of deaths from leukaemia were computed from, on average, 18 months after first treatmentthat is, from the beginning of the second year after the year of first treatment (no deaths from leukaemia occurred in the year after the year of first treatment). The case notes were reviewed for the four patients in the series whose cause of death was given on their death certificate as aplastic anaemia, ${ }^{1}$ and for two (who died at two and four years after first treatment for spondylitis) it was considered that death was actually due to leukaemia. Leukaemia was also recorded on the death certificate, though not as the underlying cause of death, for five other patients (who died at $5,6,10,12$, and 16 years after first treatment). The lower section of table $\mathrm{V}$ shows the estimated excess death rates with leukaemia when these additional seven patients were included. No data for the study period were available for deaths in England and Wales as a whole with leukaemia mentioned on the death certificate but not as the underlying cause of death, nor was there information on the number of deaths from leukaemia that were certified as due to aplastic anaemia. We assumed that the ratio of the number of such deaths to the number of deaths for which leukaemia was certified as the underlying cause was the same as we observed in our study series. Thus to estimate the number of deaths with leukaemia that would have been expected based on England and Wales mortality rates (including those for which leukaemia was not the certified cause) we multiplied the expected numbers based on the underlying cause (table IV) by $35 / 28$ - that is, the total number of deaths with leukaemia in the study series two or more years after first treatment divided by the number for which leukaemia was certified as the underlying cause. The revised expected numbers are shown in the lower section of table V. In the period from the second year after first treatment the excess death rate with leukaemia was estimated to be 24.5 per 100000 person-years at risk.

Cancer of the colon-The ratio of observed to expected deaths from cancer of the colon, 1.62:1 (table III; $p<0.05$ ), was similar to that for cancers of the heavily irradiated sites $(1 \cdot 55: 1)$. The ratio was highest in the period immediately after the first treatment course, with six deaths in the 18 months immediately after radiotherapy (table IV). Subsequently there was still a statistically significant excess $(p=0.05)$, but within this period there was no significant change in the ratio of observed to expected deaths with time since entry to the study.

Cancers of lightly irradiated sites-There was a $20 \%$ excess of 
deaths from cancers of sites that were considered to be lightly irradiated, but this was not quite statistically significant (table III $p=0.06$ ). There was no significant change in the ratio of observed to expected deaths with time since first treatment (table IV). The observed and expected deaths associated with the individual sites that were classified as "lightly irradiated" are shown in table VI, divided according to whether they occurred in the first two years after radiotherapy or later. (The reasons for considering separately the first two years after radiotherapy are discussed in the next section.) Three or more years after first treatment there were excess numbers of deaths from cancers of several sites, but in no case was the excess statistically significant, nor was the variation in the ratio of observed to expected deaths for each site. The only significant excess of deaths in the first two years after treatment was for cancer of the prostate, with three deaths against 0.7 expected $(p<0 \cdot 05)$. Two of these occurred in the same year as the first treatment for spondylitis and may have caused the symptoms that were attributed to spondylitis.

Cancers of heavily irradiated sites-There was a 55\% excess of cancers of sites judged to be directly in the radiation beams, a statistically highly significant excess (table III; $p<0.001$ ). The ratio of observed to expected deaths was high in the two years after first treatment (see footnote to table IV), fell to a minimum at six to eight years after treatment; and then rose to remain above 1.5:1 for the next
12 years. From nine or more years after treatment the ratio of the observed to the expected number of deaths declined progressively, but the trend was not statistically significant $\left(\chi^{2}(1 \mathrm{df}\right.$ trend : $9-11$ years, ... $\geqslant 24$ years $)=3.34 ; \mathrm{p}=0.07$ ). The excess death rate (table $\mathrm{V}$ ) also fell to a minimum at six to eight years after treatment and then rose to maintain a roughly constant level for the next 12 years. More than 20 years after treatment the excess rate fell, but the expected numbers were small and the downward trend was not statistically significant $\left(\chi^{2}(1 \mathrm{df}: 9-20\right.$ years $v \geqslant 21$ years $\left.)=0 \cdot 58\right)$. There was little variation in the ratio of observed to expected numbers between each of the heavily irradiated sites apart from the grossly increased figure $(10 \cdot 0: 1)$ for tumours of the spinal cord and nerves (table VII). Two of these tumours caused death within the first two years after treatment and may have caused the symptoms that were incorrectly ascribed to spondylitis. Several other types of tumour may also have presented in the same way. For example, there were five deaths from cancer of the pancreas in the first two years after treatment against 1.0 expected. In the absence of detailed clinical information, it seems desirable to exclude these early observations from analysis of the carcinogenic effects of the treatment. We therefore excluded all observations made during the first two years. The variation in the ratio of the number of observed to expected deaths by site three or more years after first treatment was statistically significant $\left(\chi^{2}(12 \mathrm{df})=29.93 ; \mathrm{p}<0.01\right)$ but this was due only to the large excess of tumours of the central nervous

TABLE VII-Observed and expected deaths from cancers of heavily irradiated sites

\begin{tabular}{|c|c|c|c|c|c|c|c|c|c|c|c|c|c|c|c|}
\hline \multirow[b]{3}{*}{ Site† } & \multirow[b]{3}{*}{.. } & \multirow[b]{3}{*}{. } & \multirow[b]{3}{*}{. } & \multirow[b]{3}{*}{. } & \multirow[b]{3}{*}{.. } & \multirow[b]{3}{*}{. } & \multicolumn{6}{|c|}{ Time since first treatment (years) } & \multirow{2}{*}{\multicolumn{3}{|c|}{ Total }} \\
\hline & & & & & & & \multicolumn{3}{|c|}{$0-2$} & \multicolumn{3}{|c|}{$\geqslant 3$} & & & \\
\hline & & & & & & & Observed & Expected & $\mathrm{O} / \mathrm{E}$ & Observed & Expected & $\mathrm{O} / \mathrm{E}$ & Observed & Expected & $\mathrm{O} / \mathrm{E}$ \\
\hline \multirow{2}{*}{\multicolumn{2}{|c|}{$\begin{array}{l}\text { Pharynx... } \\
\text { Oesopn agus }\end{array}$}} & $\ldots$ & $\ldots$ & $\ldots$ & $\ldots$ & $\ldots$ & 0 & $0 \cdot 20$ & 0.00 & 3 & 1.29 & $2 \cdot 33$ & 3 & 1.50 & 2.00 \\
\hline & & $\therefore$ & $\therefore$ & $\therefore$ & $\therefore$ & $\therefore$ & 0 & 0.67 & 0.00 & $10^{*}$ & 4.90 & 2.04 & 10 & 5.57 & 1.80 \\
\hline \multicolumn{2}{|c|}{ Stomach } & $\therefore$ & $\because$ & $\because$ & $\therefore$ & $\because$ & 6 & 5.04 & $1 \cdot 19$ & $39 *$ & $29 \cdot 12$ & 1.34 & $45 *$ & $34 \cdot 16$ & 1.32 \\
\hline \multicolumn{2}{|c|}{$\begin{array}{l}\text { Stomach } \\
\text { Pancreas }\end{array}$} & $\because$ & $\because$ & $\because$ & $\because$ & $\because$ & $5 * *$ & $\begin{array}{l}3.00 \\
1.00\end{array}$ & 5.00 & 13 & 8.48 & 1.53 & $18^{* *}$ & 9.48 & $\begin{array}{l}1.92 \\
1.90\end{array}$ \\
\hline \multicolumn{2}{|c|}{$\begin{array}{l}\text { Pancreas } \\
\text { Larynx }\end{array}$} & $\therefore$ & $\therefore$ & $\therefore$ & $\therefore$ & $\therefore$ & 2 & 0.40 & 5.00 & 3 & $2 \cdot 25$ & 1.33 & 5 & 2.66 & 1.88 \\
\hline \multirow{2}{*}{\multicolumn{2}{|c|}{ Lung $\quad}}$. & $\therefore$ & $\therefore$ & $\therefore$ & $\ldots$ & $\therefore$ & 13 & 8.60 & 1.51 & $111^{* * *}$ & $78 \cdot 68$ & 1.41 & $124^{* * *}$ & $87 \cdot 28$ & 1.42 \\
\hline & & $\therefore$ & $\therefore$ & $\therefore$ & $\therefore$ & $\therefore$ & 0 & 0.48 & 0.00 & 4 & 2.92 & 1.37 & 4 & 3.40 & 1.18 \\
\hline \multicolumn{2}{|c|}{$\begin{array}{l}\text { Ovaries } \\
\text { Skin }\end{array}$} & $\therefore$ & $\because$ & $\therefore$ & $\therefore$ & $\therefore$ & 0 & 0.31 & 0.00 & 0 & $1 \cdot 88$ & 0.00 & $\begin{array}{l}4 \\
0\end{array}$ & $2 \cdot 19$ & 0.00 \\
\hline \multirow{2}{*}{\multicolumn{5}{|c|}{ Bones (excluding nose and jaw) }} & $\because$ & $\because$ & 1 & 0.34 & 2.94 & 3 & 0.96 & 3.13 & $4^{*}$ & 1.30 & 3.08 \\
\hline & & & & & $\because$ & $\because$ & 2 & 0.73 & $2 \cdot 74$ & 2 & $2 \cdot 84$ & 0.70 & 4 & 3.57 & $\begin{array}{l}3.12 \\
1.12\end{array}$ \\
\hline \multicolumn{5}{|c|}{ Hodgkin's disease $\quad . . \quad \ldots$} & .. & .. & 1 & 0.75 & 1.33 & $13^{* * *}$ & 5.02 & 2.59 & $14^{* * *}$ & $5 \cdot 77$ & 2.43 \\
\hline \multicolumn{5}{|c|}{$\begin{array}{l}\text { Other lymphoma } \\
\text { CNS tumours (cord and nerves) }\end{array}$} & $\therefore$ & $\therefore$ & $2 * *$ & 0.09 & $22 \cdot 22$ & $4 * *$ & 0.51 & 7.84 & $6 * * *$ & 0.60 & 10.00 \\
\hline \multicolumn{5}{|c|}{$\begin{array}{l}\text { CNS tumours (cord and nerves) } \\
\text { Others } \ldots\end{array}$} & $\because$ & $\because$ & 1 & $1 \cdot 29$ & 0.78 & $21^{* * *}$ & $8 \cdot 74$ & $2 \cdot 40$ & $22^{* * *}$ & 10.03 & $2 \cdot 19$ \\
\hline \multicolumn{2}{|c|}{ Total } & $\ldots$ & .. & $\ldots$ & $\ldots$ & $\ldots$ & $33 * *$ & $19 \cdot 91$ & 1.66 & $226 * * *$ & 147.59 & 1.53 & $259 * * *$ & $167 \cdot 50$ & 1.55 \\
\hline
\end{tabular}

† ICD(7) codes are as follows: pharynx (145.7-145.9, 146-148); oesophagus (150); stomach (151); pancreas (157); larynx (161, 162.0, pt. 165); lung and pleura (162.1, 162.2, 163); ovary (175); skin (190-191); bones excluding jaw and nose (196.2-196.9); Hodgkin's disease (201); other lymphoma (200-205 less 201 and 204); CNS tumours (193, 223, rradiated sites and cancers of all lightly irradiated sites).

${ }^{*} \mathrm{p}<0.05 ; * * \mathrm{p}<0.01 ; * * * \mathrm{p}<0.001$.

TABLE VIII-Observed and expected deaths from causes other than neoplasms

\begin{tabular}{|c|c|c|c|c|c|c|c|c|c|c|}
\hline \multirow{2}{*}{\multicolumn{2}{|c|}{ Cause of death $\dagger$}} & \multicolumn{2}{|c|}{ Men } & \multirow[b]{2}{*}{$\mathrm{O} / \mathrm{E}$} & \multicolumn{3}{|c|}{ Women } & \multicolumn{3}{|c|}{ Total } \\
\hline & & Observed & Expected & & Observed & Expected & $\mathrm{O} / \mathrm{E}$ & Observed & Expected & $\mathrm{O} / \mathrm{E}$ \\
\hline $\begin{array}{l}\text { Class A: } \\
\text { Ankylosing spondylitis } \\
\text { Other arthritis and }\end{array}$ & . & $65^{* * * *}$ & $0 \cdot 13$ & $500 \cdot 00$ & $6^{* * *}$ & 0.01 & $600 \cdot 00$ & $71^{* * * *}$ & 0.13 & $546 \cdot 15$ \\
\hline $\begin{array}{ccc}\text { rheumatism } & \cdots \\
\text { Total } & \cdots & \cdots \\
\text { Class B: } & \cdots & \end{array}$ & $\because$ & $95^{* * *} 30^{* * *}$ & $1.19^{1.06}$ & $79 \cdot 83^{28 \cdot 30}$ & $14^{* * *} 8^{8 * * *}$ & $0.61^{0.60}$ & $22.95^{13.33}$ & $109^{* * *} 38^{* * *}$ & 1.80 & $60 \cdot 56^{22 \cdot 89}$ \\
\hline $\begin{array}{l}\text { Amyloid disease .. } \\
\text { Ulcerative colitis .. } \\
\text { Nephritis . . } \\
\text { Pulmonary tuberculosis } \\
\text { Chronic endocarditis } \\
\text { Pneumonia } \\
\text { Other respiratory disease }\end{array}$ & $\begin{array}{l}\cdots \\
\cdots \\
\cdots \\
\mathrm{e}\end{array}$ & $\begin{array}{c}0 \\
15^{* * *} \\
35^{* * *} \\
94^{* * *} \\
15^{* * *} \\
71^{* * *} \\
34^{* * *}\end{array}$ & $\begin{array}{r}0.21 \\
0.92 \\
10.30 \\
28.30 \\
5.90 \\
30.51 \\
14.52\end{array}$ & $\begin{array}{r}0 \cdot 00 \\
16 \cdot 30 \\
3 \cdot 40 \\
3 \cdot 32 \\
2 \cdot 54 \\
2 \cdot 33 \\
2 \cdot 34\end{array}$ & $\begin{array}{l}0 \\
6^{* * *} \\
4 \\
6 \\
2 \\
12^{*} \\
6^{*}\end{array}$ & $\begin{array}{l}0.03 \\
0.29 \\
1.75 \\
3.20 \\
0.93 \\
6.65 \\
1.82\end{array}$ & $\begin{array}{r}0 \cdot 00 \\
20 \cdot 69 \\
2 \cdot 29 \\
1 \cdot 88 \\
2 \cdot 15 \\
1 \cdot 81 \\
3 \cdot 30\end{array}$ & $\begin{array}{r}0 \\
21^{* * *} \\
39^{* * *} \\
100^{* * *} \\
17^{* * *} \\
83^{* * *} \\
40^{* * *}\end{array}$ & $\begin{array}{r}0 \cdot 24 \\
1 \cdot 20 \\
12 \cdot 05 \\
31 \cdot 50 \\
6 \cdot 83 \\
37 \cdot 16 \\
16 \cdot 34\end{array}$ & $\begin{array}{r}0 \cdot 00 \\
17 \cdot 50 \\
3 \cdot 24 \\
3 \cdot 17 \\
2 \cdot 49 \\
2 \cdot 23 \\
2 \cdot 45\end{array}$ \\
\hline $\begin{array}{ccc}\text { Total } & \cdots & \cdots \\
\text { Class } & C: & \end{array}$ & . & $264^{* * *}$ & 90.67 & 2.91 & $36 * * *$ & 14.66 & $2 \cdot 46$ & $300 * * *$ & $105 \cdot 33$ & $2 \cdot 85$ \\
\hline $\begin{array}{l}\text { Aplastic anaemia } \\
\text { All neoplasms } \quad . \\
\text { Class D: } \\
\text { Other gastrointestinal }\end{array}$ & $\begin{array}{l}\cdots \\
\cdots\end{array}$ & $\begin{array}{r}4 * * * \\
339 * * *\end{array}$ & $\begin{array}{r}0 \cdot 42 \\
214 \cdot 19\end{array}$ & $\begin{array}{l}9.52 \\
1.58\end{array}$ & $\begin{array}{l}0 \\
58 *\end{array}$ & $\begin{array}{r}0 \cdot 11 \\
42 \cdot 73\end{array}$ & $\begin{array}{l}0.00 \\
1.36\end{array}$ & $\begin{array}{c}4 * * \\
397^{* * *}\end{array}$ & $\begin{array}{r}0.54 \\
256.92\end{array}$ & $\begin{array}{l}7 \cdot 41 \\
1.55\end{array}$ \\
\hline 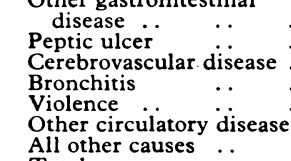 & $\begin{array}{l}\ldots \\
\cdots \\
\cdots \\
\mathrm{e} \\
\cdots\end{array}$ & $\begin{array}{c}31^{* * *} \\
20^{*} \\
92^{*} \\
88^{* *} \\
76^{*} \\
409^{* * *} \\
77^{* *}\end{array}$ & $\begin{array}{r}15 \cdot 60 \\
13.06 \\
75 \cdot 14 \\
66 \cdot 88 \\
61.41 \\
305 \cdot 54 \\
56 \cdot 15\end{array}$ & $\begin{array}{l}1.99 \\
1.53 \\
1.22 \\
1.32 \\
1.24 \\
1.34 \\
1.37\end{array}$ & $\begin{array}{c}8^{*} \\
2 \\
28 \\
4 \\
13^{*} \\
67^{* *} \\
31^{* * *}\end{array}$ & $\begin{array}{r}3.71 \\
0.95 \\
23.51 \\
5.58 \\
6.51 \\
49.75 \\
13.24\end{array}$ & $\begin{array}{l}2 \cdot 16 \\
2 \cdot 11 \\
1 \cdot 19 \\
0 \cdot 72 \\
2 \cdot 00 \\
1 \cdot 35 \\
2 \cdot 34\end{array}$ & $\begin{array}{c}39^{* * *} \\
22^{*} \\
120^{*} \\
92^{*} \\
89^{* *} \\
476^{* * *} \\
108^{* * *}\end{array}$ & $\begin{array}{r}19.31 \\
14.00 \\
98.65 \\
72.46 \\
67.91 \\
355.28 \\
69.40\end{array}$ & $\begin{array}{r}2.02 \\
1.57 \\
1.22 \\
1.27 \\
1.31 \\
1.34 \\
1.56\end{array}$ \\
\hline $\begin{array}{cc}\text { Total } & \ldots \\
\text { Cause unknown } & \cdots\end{array}$ & $\because$ & $793 * * * 3$ & $593 \cdot 78$ & 1.34 & $153^{* * * *} 0$ & $103 \cdot 25$ & 1.48 & $946 * * *$ & 697.03 & 1.36 \\
\hline
\end{tabular}

ICD(7) codes are as follows: Class A: ankylosing spondylitis (722.1); other arthritis and rheumatism (rest of 720-727). Class B: Amyloid disease (289.1); ulcerative colitis (572.1); nephritis (590-594); pulmonary tuberculosis (001-008); chronic endocarditis (421); pneumonia (490-493); other respiratory disease (rest of 470-527). Class C: aplastic (500-502, 526); violence (800-999); other circulatory disease (rest of 400-468). 
system (CNS) and the variation between the other sites was not significant $\left(\chi^{2}(11 \mathrm{df})=16 \cdot 86 ; p>0 \cdot 10\right)$. Of the four deaths ascribed to CNS tumours three or more years after treatment two occurred at four years and may possibly have been present when treatment was started. The excess death rate from cancers of all heavily irradiated sites combined, three or more years after first treatment was estimated to be 77.3 per 100000 person-years at risk, with $95 \%$ confidence limits of $48 \cdot 2$ to $106 \cdot 3$ per 100000 person-years at risk.

TABLE IX-Observed and expected deaths from cancers of heavily irradiated site three or more years after first treatment by age at first treatment

\begin{tabular}{|c|c|c|c|c|c|}
\hline \multirow[b]{2}{*}{$\begin{array}{l}\text { Age at first } \\
\text { treatment } \\
\text { (years) }\end{array}$} & \multicolumn{5}{|c|}{ Cancers of heavily irradiated sites } \\
\hline & Observed & Expected & $\mathrm{O} / \mathrm{E}$ & $\begin{array}{c}\text { Person } \\
\text { years at risk }\end{array}$ & $\begin{array}{c}\text { Excess risk } \\
/ 10^{5} / \text { year }\end{array}$ \\
\hline $\begin{array}{r}<25 \\
25-34 \\
35-44 \\
45-54 \\
\geqslant 55\end{array}$ & $\begin{array}{r}5 \\
29 \\
80 \\
69 \\
43\end{array}$ & $\begin{array}{r}2.65 \\
19.45 \\
46.76 \\
48.37 \\
30.36\end{array}$ & $\begin{array}{l}1.89 \\
1.49 \\
1.71 \\
1.43 \\
1.42\end{array}$ & $\begin{array}{r}14957 \\
37957 \\
29877 \\
13667 \\
4982\end{array}$ & $\begin{array}{r}15.7 \\
25 \cdot 2 \\
111.3 \\
151.0 \\
253.7\end{array}$ \\
\hline Total & 226 & $147 \cdot 59$ & 1.53 & 101440 & $77 \cdot 3$ \\
\hline
\end{tabular}

patients with spondylitis. In fact, however, they were also in excess in $>$ patients with spondylitis,,$^{210}$ and this was confirmed by our data, based $\stackrel{\varnothing}{\varrho}$ on a longer period of follow-up. The relative excesses, however, were $c$ less than those for diseases in classes $\mathrm{A}$ and $\mathrm{B}$ (other than amyloid $\widehat{\widehat{O}}$ disease).

The findings for the different causes of death were similar in both sexes (table VIII). Overall there was a $69 \%$ excess of deaths from $\mathbb{D}$ causes other than neoplasms, and the ratio of observed to expected deaths from these causes remained approximately constant at different $\varrho$ times after irradiation (table IV).

\section{EFFECT OF AGE AT FIRST TREATMENT}

\section{Cancers of heavily irradiated sites}

In table IX the numbers of observed and expected deaths from cancers of heavily irradiated sites occurring three or more years after $\infty$ first treatment were divided into five groups according to the age of the $\overrightarrow{0}$ patient when first treated. The results provide no evidence of any change in the ratio with age $\left(\chi^{2}(1 \mathrm{df}\right.$ trend $\left.)=0.74 ; \mathrm{p}>0.20\right)$. Excess $\vec{\omega}$ death rates, however, increased rapidly with increasing age at first $\mathrm{O}$ treatment $\left(\chi^{2}(1 \mathrm{df}\right.$ trend $\left.)=14.94 ; \mathrm{p}<0.001\right)$. Among patients first $\frac{0}{3}$ treated at the age of 55 years or more the excess death rate from cancers

TABLE X-Observed and expected deaths from cancers of heavily irradiated sites three or more years after first treatment by age at first treatment and time since first treatment

\begin{tabular}{|c|c|c|c|c|c|c|}
\hline \multirow{2}{*}{$\begin{array}{l}\text { Age at first } \\
\text { treatment }\end{array}$} & \multicolumn{4}{|c|}{ Time since first treatment (years) } & \multirow[b]{2}{*}{ Total } & \multirow{2}{*}{$\begin{array}{l}\text { Excess risk } \\
\text { standardised } \\
\text { for time since } \\
\text { first treatment }\end{array}$} \\
\hline & $3-8$ & $9-14$ & $15-20$ & $\geqslant 21$ & & \\
\hline $\begin{array}{l}\text { 25 years: } \\
\text { Observed } \\
\text { Expected } \\
\text { O/E } \\
\text { Years at risk } \\
\text { Excess risk }\end{array}$ & $\begin{array}{c}1 \\
0 \cdot 49 \\
2 \cdot 0 \\
6117 \\
8 \cdot 3\end{array}$ & $\begin{array}{c}0 \\
0 \cdot 64 \\
0 \cdot 0 \\
4668 \\
(-13 \cdot 7)\end{array}$ & $\begin{array}{c}4 \\
0 \cdot 85 \\
4 \cdot 7 \\
3132 \\
100 \cdot 6\end{array}$ & $\begin{aligned} & 0 \\
& 0 \cdot 67 \\
& 0 \cdot 0 \\
& 1040 \\
&(-64.4)\end{aligned}$ & $\begin{aligned} & 5 \\
& 2 \cdot 65 \\
& 1.89 \\
& 14957 \\
& 15 \cdot 7\end{aligned}$ & $16 \cdot 1$ \\
\hline $\begin{array}{l}\text { 25-34 years } \\
\text { Observed } \\
\text { Expected } \\
\text { O/E } \\
\text { Years at risk } \\
\text { Excess risk }\end{array}$ & $\begin{array}{c}1 \\
2 \cdot 92 \\
0 \cdot 3 \\
15583 \\
(-12 \cdot 3)\end{array}$ & $\begin{aligned} & 9 \\
& 5 \cdot 24 \\
& 1 \cdot 7 \\
& 12369 \\
& 30 \cdot 4\end{aligned}$ & $\begin{array}{c}14 \\
7 \cdot 17 \\
2 \cdot 0 \\
7945 \\
86.0\end{array}$ & $\begin{array}{c}5 \\
4 \cdot 12 \\
1 \cdot 2 \\
2059 \\
42 \cdot 7\end{array}$ & $\begin{array}{c}29 \\
19 \cdot 45 \\
1.49 \\
37957 \\
25 \cdot 2\end{array}$ & $23 \cdot 7$ \\
\hline $\begin{array}{l}\text { 35-44 years } \\
\text { Observed } \\
\text { Expected } \\
\text { O/E } \\
\text { Years at risk } \\
\text { Excess risk }\end{array}$ & $\begin{array}{c}15 \\
8 \cdot 99 \\
1 \cdot 7 \\
12656 \\
47 \cdot 5\end{array}$ & $\begin{array}{c}32 \\
15 \cdot 18 \\
2 \cdot 1 \\
9863 \\
170 \cdot 5\end{array}$ & $\begin{array}{c}26 \\
17 \cdot 00 \\
1 \cdot 5 \\
6160 \\
146 \cdot 1\end{array}$ & $\begin{array}{c}7 \\
5 \cdot 59 \\
1 \cdot 3 \\
1199 \\
117 \cdot 6\end{array}$ & $\begin{array}{rl} & 80 \\
& 46 \cdot 76 \\
& 1 \cdot 71 \\
29 & 877 \\
111 \cdot 3\end{array}$ & 110.5 \\
\hline $\begin{array}{l}\text { 45-54 years } \\
\text { Observed } \\
\text { Expected } \\
\text { O/E } \\
\text { Years at risk } \\
\text { Excess risk }\end{array}$ & $\begin{array}{c}17 \\
14 \cdot 39 \\
1 \cdot 2 \\
6419 \\
40 \cdot 7\end{array}$ & $\begin{array}{c}33 \\
18 \cdot 49 \\
1.8 \\
4667 \\
310.9\end{array}$ & $\begin{array}{c}17 \\
13 \cdot 38 \\
1 \cdot 3 \\
2304 \\
157 \cdot 1\end{array}$ & $\begin{array}{c}2 \\
2 \cdot 10 \\
1 \cdot 0 \\
277 \\
(-36 \cdot 1)\end{array}$ & $\begin{array}{c}\quad 69 \\
48 \cdot 37 \\
1 \cdot 43 \\
13667 \\
151 \cdot 0\end{array}$ & $148 \cdot 6$ \\
\hline $\begin{array}{l}\geqslant 55 \text { years } \\
\text { Observed } \\
\text { Expected } \\
\text { O/E } \\
\text { Years at risk } \\
\text { Excess risk }\end{array}$ & $\begin{array}{c}17 \\
13 \cdot 51 \\
1 \cdot 3 \\
2661 \\
131 \cdot 2\end{array}$ & $\begin{array}{c}17 \\
10 \cdot 87 \\
1 \cdot 6 \\
1580 \\
388 \cdot 0\end{array}$ & $\begin{array}{l}8 \\
5 \cdot 29 \\
1 \cdot 5 \\
652 \\
415 \cdot 6\end{array}$ & $\begin{array}{c}1 \\
0 \cdot 69 \\
1 \cdot 4 \\
89 \\
348 \cdot 3\end{array}$ & $\begin{array}{c}43 \\
30 \cdot 36 \\
1 \cdot 42 \\
4982 \\
253 \cdot 7\end{array}$ & $281 \cdot 7$ \\
\hline $\begin{array}{l}\text { Total } \\
\text { Observed } \\
\text { Expected } \\
\text { O/E } \\
\text { Years at risk } \\
\text { Excess risk }\end{array}$ & $\begin{array}{cc} & 51 \\
& 40 \cdot 31 \\
& 1 \cdot 27 \\
43436 & \\
& 24 \cdot 6\end{array}$ & $\begin{array}{cl} & 91 \\
& 50 \cdot 42 \\
& 1 \cdot 80 \\
33 & 147 \\
& 122 \cdot 4\end{array}$ & $\begin{array}{rl} & 69 \\
& 43 \cdot 70 \\
& 1 \cdot 58 \\
20 & 193 \\
& 125 \cdot 3\end{array}$ & $\begin{array}{c}15 \\
13 \cdot 16 \\
1 \cdot 14 \\
4664 \\
39 \cdot 4\end{array}$ & $\begin{array}{c}226 \\
147.59 \\
1.53 \\
101440 \\
77.3\end{array}$ & \\
\hline $\begin{array}{l}\text { Excess risk standarc } \\
\text { for age at lst } \\
\text { treatment }\end{array}$ & $22 \cdot 5$ & 120.5 & $131 \cdot 6$ & $53 \cdot 4$ & & \\
\hline
\end{tabular}

Excess risk is per 100000 years at risk.

\section{Diseases other than neoplasms}

In their 1965 report Court Brown and Doll ${ }^{2}$ classified the causes of death into four classes. Class A consisted of ankylosing spondylitis and other diseases of the joints, some of which might give rise to diagnostic confusion, while class B consisted of diseases that were known to be associated with spondylitis (table VIII) (we classed colon cancer with all other cancers in class $C$ whereas previously it was in class B). Except for amyloid disease the numbers of deaths from all of the causes in classes $\mathrm{A}$ and $\mathrm{B}$ were significantly greater than expected (in each case $\mathrm{p}<0.001$ ). The largest excesses were for ankylosing spondylitis, arthritis and rheumatism, and ulcerative colitis.

Class C consisted of aplastic anaemia and neoplasms, which we have commented on already. Class D included all those causes of death for which it was thought that mortality might be close to normal among of heavily irradiated sites was more than 15 times that of patients first $\bar{\sigma}$ treated under the age of 25 years.

Table X shows the person-years at risk and the numbers of deaths $\frac{\mathrm{C}}{\mathrm{D}}$ from cancers of heavily irradiated sites observed and expected three or $\Phi$ more years after first treatment, by age at first treatment and time since first treatment. Patients under the age of 25 years when first treated had lower death rates from all causes combined than patients first $\overrightarrow{\mathbb{D}}$ treated at older ages and they therefore contributed a higher proportion $\frac{\cap}{\mathbb{D}}$ of the person-years at risk 21 or more years after first treatment than at earlier periods $(22 \%$ against $14 \%$ between three and eight years after $\underset{\gamma}{ }$ first treatment). Therefore the decline in the excess death rate from $\Omega$ cancer of the heavily irradiated sites 21 or more years after first $\frac{0}{0}$ treatment, which is shown in table $\mathrm{V}$, was partly an artefact due to the increasing proportion of young people among the survivors with the passage of time. In table $\mathrm{X}$ we, therefore, show the excess death rate $\stackrel{?}{?}$ 
at different times after first treatment, standardised for age at first treatment. Adoption of this procedure slightly increases the estimate of the excess rates 21 or more years after treatment but does not eliminate the fall. Table $\mathrm{X}$ also shows the excess death rates at different ages at first treatment, standardised in a similar manner for time after first treatment. These rates show a slightly steeper rise with age at first treatment than the unadjusted rates in table IX.

\section{Leukaemia}

Table XI shows the change in risk of death from leukaemia two or more years after first treatment according to the age of the patients when treated. There was a statistically significant increase in the excess death rate from leukaemia among patients first irradiated at an old age $\left(\gamma^{2}(1 \mathrm{df}\right.$ trend $\left.)=6.73 ; \mathrm{p}<0.01\right)$ but no evidence of any appreciable change in the ratio of observed to expected deaths with age at first treatment $\left(\chi^{2}(1 \mathrm{df}\right.$ trend $\left.)=0.03 ; \mathrm{p}>0.80\right)$.

\section{EXCESS MORTALITY RELATED TO RADIATION DOSE}

\section{Leukaemia}

The estimated mean bone marrow radiation dose associated with the first course of treatment among the 903 patients for whom full data on radiation treatment were extracted from radiotherapy records (table II) was 321 rads. (There was a higher proportion of patients with insufficient data for dose estimation in sampling classes 4 and 5 than in sampling classes 1 to 3 (table 2). As patients in sampling class 4 for whom a dose estimate was made had a lower mean dose than those in sampling class 1 , the exclusion of patients with insufficient data probably overestimated the mean dose to the whole group. If we assume, however, that patients with insufficient data received, on average, the same dose as those in the same sampling class for whom sufficient data were available, we estimate that the mean dose to the whole population was 319.9 rads, which is close to that obtained when the patients with insufficient data were ignored (320.8 rads). In subsequent computations only the patients with estimated doses were

TABLE XI-Observed and expected deaths from leukaemia and all causes except neoplasms two or more years after first treatment by age at first treatment

\begin{tabular}{|c|c|c|c|c|c|c|c|c|c|}
\hline \multirow[b]{2}{*}{$\begin{array}{c}\text { Age at first } \\
\text { treatment (years) }\end{array}$} & \multicolumn{4}{|c|}{ Leukaemia } & \multicolumn{5}{|c|}{ All causes except neoplasms } \\
\hline & Observed & Expected & $\mathrm{O} / \mathrm{E}$ & $\begin{array}{l}\text { Person- } \\
\text { y'ears at } \\
\text { at risk }\end{array}$ & $\begin{array}{l}\text { Excess risk } \\
/ 10^{5} / \text { year }\end{array}$ & Observed & Expected & $\mathbf{O} / \mathbf{E}$ & $\begin{array}{l}\text { Excess risk } \\
/ 10^{5} / \text { year }\end{array}$ \\
\hline $\begin{array}{r}<25 \\
25-34 \\
35-44 \\
45-54 \\
\geqslant 55\end{array}$ & $\begin{array}{l}1(1) \\
7(8) \\
8(9) \\
8(10) \\
4(7)\end{array}$ & $\begin{array}{l}0.40(0.50) \\
1.35(1.68) \\
1.71(2.14) \\
1.39(1.74) \\
1.00(1.25)\end{array}$ & $\begin{array}{l}2 \cdot 50(2 \cdot 00) \\
5 \cdot 19(4 \cdot 76) \\
4 \cdot 68(4 \cdot 21) \\
5 \cdot 76(5 \cdot 75) \\
4 \cdot 00(5 \cdot 60)\end{array}$ & $\begin{array}{r}1667 \mathrm{i} \\
42099 \\
33111 \\
15335 \\
5743\end{array}$ & $\begin{array}{c}3.6(3.0) \\
13 \cdot 4(15 \cdot 0) \\
19 \cdot 0(20 \cdot 7) \\
43 \cdot 1(53 \cdot 9) \\
52 \cdot 2(100 \cdot 1)\end{array}$ & $\begin{array}{r}64 \\
182 \\
341 \\
317 \\
312\end{array}$ & $\begin{array}{r}22 \cdot 20 \\
96 \cdot 94 \\
175 \cdot 48 \\
197 \cdot 14 \\
233.54\end{array}$ & $\begin{array}{l}2.88 \\
1.88 \\
1.94 \\
1.61 \\
1.34\end{array}$ & $\begin{array}{r}250 \cdot 7 \\
202 \cdot 1 \\
499 \cdot 1 \\
782 \cdot 1 \\
1366 \cdot 2\end{array}$ \\
\hline Total & $28(35)$ & $5 \cdot 85(7 \cdot 31)$ & $4 \cdot 79(4 \cdot 79)$ & 112960 & $19 \cdot 6(24 \cdot 5)$ & 1216 & $725 \cdot 30$ & $1 \cdot 68$ & $434 \cdot 3$ \\
\hline
\end{tabular}

Numbers in parentheses include 7 deaths for which leukaemia was not the primary cause but for which leukaemia was the preferred diagnosis or was mentioned on the death certificate.

Table XII shows the excess death rate at different periods after irradiation standardised for the age at which patients were irradiated. Standardisation for differences between the age at treatment groups in the distribution of years at risk between the different follow-up periods explained only a small portion of the reduction in excess risk with time since irradiation (compare with table V). Similarly standardisation for time after first treatment had only little effect on the pattern of excess death rates by age at first treatment (after standardisation the excess risks $/ 10^{5} /$ year were: $<25$ years, 3.8; $23-34$ years, $14.0 ; 35-44$ years, $19 \cdot 0 ; 45-54$ years, $45 \cdot 5$; and $\geqslant 55$ years, $38 \cdot 2$ (compare with table XI))

TABLE XII-Observed and expected deaths from leukaemia two or more years after first treatment according to time since the radiation exposure standardised by age at first treatment

\begin{tabular}{|c|c|c|c|c|c|}
\hline & \multicolumn{4}{|c|}{ Time since first treatment (years) } & \multirow[b]{2}{*}{ Total } \\
\hline & $2-5$ & $6-11$ & $12-17$ & $\geqslant 18$ & \\
\hline $\begin{array}{l}\text { Deaths from leukaemia } \\
\text { Observed } \\
\text { Expected } \\
\text { Years at risk } \\
\text { Excess risk* }\end{array}$ & $\begin{array}{c}13 \\
1 \cdot 27 \\
35476 \\
33 \cdot 1\end{array}$ & 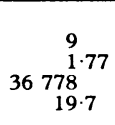 & $\begin{array}{c}5 \\
1 \cdot 86 \\
28819 \\
10 \cdot 9\end{array}$ & $\begin{array}{c}1 \\
0.96 \\
11897 \\
0.3\end{array}$ & $\begin{array}{c}28 \\
5 \cdot 85 \\
112970 \\
19 \cdot 6\end{array}$ \\
\hline $\begin{array}{l}\text { Excess risk standardised } \\
\text { for age at } \\
\text { irradiation }\end{array}$ & $31 \cdot 8$ & $19 \cdot 3$ & $10 \cdot 8$ & $4 \cdot 2$ & $19 \cdot 6$ \\
\hline
\end{tabular}

* Per 100000 years at risk.

\section{Causes other than neoplasms}

For all causes other than leukaemia or other cancers the ratio of total observed to expected deaths was highest among those first treated under the age of 25 years and lowest among those first treated at age 55 years or above (table XI). The decline in the value of the ratio with age at treatment was highly significant $\left(\chi_{1}^{2}\right.$ (trend) $\left.=38.3 ; p<0.001\right)$. Conversely, however, the excess death rate increased with increasing age at first treatment (though much less rapidly than the excess death rate from cancers of heavily irradiated sites), and this trend was also highly significant $\left(\chi^{2}\right.$ (trend $\left.)=54.3 ; \mathrm{p}<0.001\right)$. considered.) The mean dose for the 756 men in the sample ( 323 rads) was greater than that for the 147 women ( 310 rads), but the difference was insignificant. Patients who had more than one course of treatment tended to receive a lower dose of radiation in their first course than those receiving only one (table II). Fig 1 shows the distribution of the estimated mean marrow dose in the total sample of 903 patients. The distribution was fairly uniform between 50 and 550 rads, but only $2.1 \%$ of patients had estimated doses of over 650 rads.

When computing the excess death rate from leukaemia the year of first treatment and the next year were excluded from the analysis as

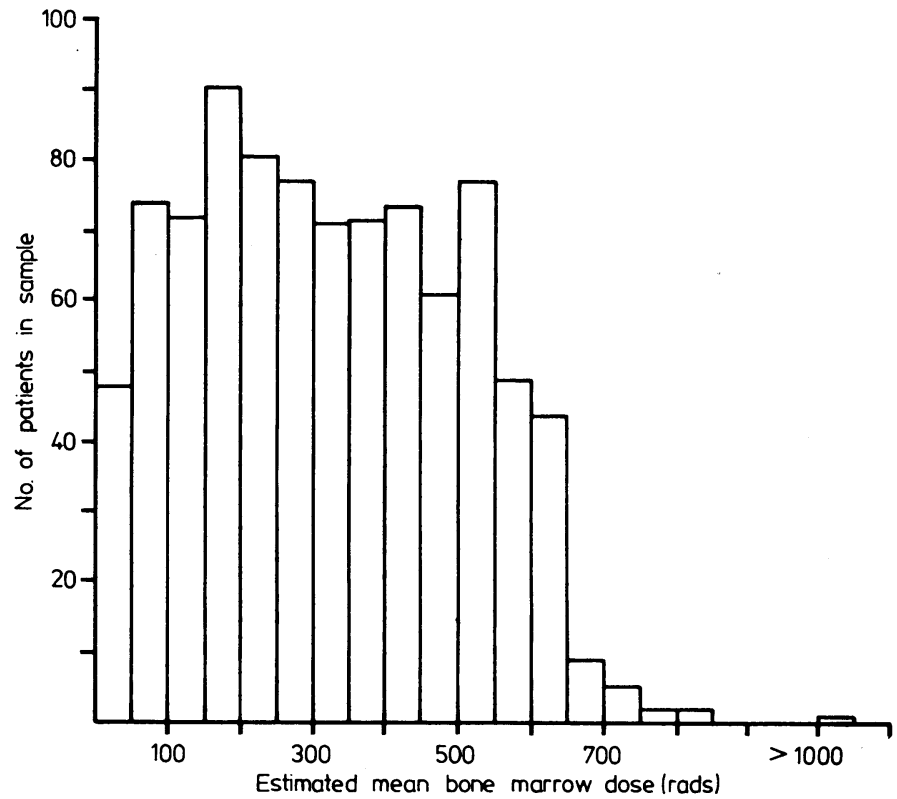

FIG 1-Distribution of estimated mean bone marrow doses from first course of radiation treatment among random sample of 903 patients with ankylosing spondylitis. 
three leukaemias diagnosed shortly after first treatment were considered to have been present at the time of first treatment for ankylosing spondylitis. There were 146 patients in the sample who were not followed up beyond the year after treatment (including those who were retreated for spondylitis in the same year as their initial treatment). These patients received, on average, a bone marrow dose of 249 rads from their first course, whereas the 757 patients followed for longer received on average a dose of 335 rads. Only the latter patients were included in subsequent analyses.

Information was obtained for all but one of the patients dying with leukaemia, and the distribution of the estimated mean marrow doses is shown in table XIII together with the marrow dose estimates for those followed beyond the year after the year of first treatment. For the patient whose treatment details were missing the mean spinal marrow dose of radiation had been estimated previously. ${ }^{1}$ The new estimate of the mean marrow dose and the original estimate of mean spinal marrow dose were compared for 12 patients who had died of leukaemia and for whom both estimates were available (estimates of mean spinal doses for patients who did not develop leukaemia were no longer available). The relationship between the two estimates was reasonably well represented by a straight line, passing through the origin, with slope leukaemia ( 1 patient): 376 rads; acute myeloid leukaemia ( 18 patients): 403 rads; acute leukaemia ( 5 patients): 422 rads; and chronic myeloid leukaemia (3 patients): 464 rads). Thus, in our data there was no evidence to suggest that patients irradiated for ankylosing spondylitis had an increased risk of developing chronic lymphatic leukaemia. No excess risk of this form of leukaemia has been reported among the atomic bomb survivors, ${ }^{11}$ and this disease may not be as readily susceptible to induction by radiation as other forms of leukaemia.

\section{Cancers other than leukaemia}

The average radiation doses received by 10 organs, as estimated by the BEIR committee, ${ }^{9}$ are shown in table XIV. We related the doses to the excess mortality observed from cancers of these sites in the periods three or more years after irradiation and nine or more years after irradiation. The latter period was used as there was little evidence of any increased risk from cancer (except leukaemia) during the first eight years after treatment. Following the BEIR Committee ${ }^{9}$ we related the excess of lymphomas other than Hodgkin's disease to the

TABLE XIII-Estimated mean bone marrow dose received by patients dying of leukaemia and by random sample of patients followed up beyond year after year of first treatment

\begin{tabular}{|c|c|c|c|c|c|c|c|}
\hline $\begin{array}{c}\text { Mean } \\
\text { marrow } \\
\text { dose (rads) }\end{array}$ & $\begin{array}{c}\text { No of } \\
\text { patients } \\
\text { in sample }\end{array}$ & $\begin{array}{c}\text { Mean } \\
\text { dose (rads) }\end{array}$ & $\begin{array}{c}\text { Mean age at } \\
\text { treatment } \\
\text { (years) }\end{array}$ & $\begin{array}{l}\text { Person years at } \\
\text { risk of those in } \\
\text { sample (mean) }\end{array}$ & $\begin{array}{c}\text { Deaths from } \\
\text { leukaemia* }\end{array}$ & $\begin{array}{l}\text { Expected } \\
\text { deaths }\end{array}$ & $\begin{array}{l}\text { Excess deaths } \\
/ 10^{5} \text { person } \\
\text { years at risk }\end{array}$ \\
\hline $\begin{array}{l}0- \\
100- \\
200- \\
300- \\
400- \\
500- \\
\geqslant 600\end{array}$ & $\begin{array}{r}89 \\
120 \\
129 \\
130 \\
120 \\
109 \\
60\end{array}$ & $\begin{array}{r}55 \cdot 4 \\
153 \cdot 2 \\
250 \cdot 0 \\
348 \cdot 5 \\
447 \cdot 0 \\
540.9 \\
663.0\end{array}$ & $\begin{array}{l}38 \cdot 1 \\
38 \cdot 4 \\
36 \cdot 8 \\
35 \cdot 6 \\
34 \cdot 4 \\
35 \cdot 8 \\
37 \cdot 8\end{array}$ & $\begin{array}{r}824.5(9.3) \\
1307.0(10.9) \\
1475.5(11.4) \\
1710.0(13.2) \\
1506.0(12.6) \\
1406.0(12.9) \\
706.0(11.8)\end{array}$ & $\begin{array}{l}2(1) \dagger \\
7(1) \\
3(1) \\
4(0) \\
3(2) \\
6(2) \\
3(0)\end{array}$ & $\begin{array}{l}0.54 \\
0.86 \\
0.97 \\
1.12 \\
0.99 \\
0.92 \\
0.46\end{array}$ & $\begin{array}{l}14.0 \\
37.2 \\
10.9 \\
13 \cdot 3 \\
10.6 \\
28.6 \\
28.5\end{array}$ \\
\hline Total & 757 & $334 \cdot 6$ & $36 \cdot 6$ & $8935 \cdot 0(11 \cdot 8)$ & $28(7)$ & $5 \cdot 85$ & $19 \cdot 6$ \\
\hline
\end{tabular}

* Two or more years after first treatment (on average 18 months or more, see footnote to table IV).

+ Numbers in parentheses are not included in adjacent figures and relate to number of patients who died with leukaemia but did not have leukaemia given as underlying cause of death on death certificates.

equal to about 0.57 (mean marrow dose $=0.57 \times$ mean spinal dose) and this line was used to estimate the mean marrow dose for this patient.) The Appendix shows the individual estimates for all the patients who died with leukaemia. Table XIII also shows the person-years at risk contributed by patients in the sample in each dose group. Consistent with the finding that those followed for, on average, less than 18 months received lower doses than those followed for longer periods, those receiving less than 100 rads to the bone marrow were followed, on average, for a slightly shorter period than those receiving higher radiation doses. The distribution of person-years at risk in the sample was used to apportion the expected number of deaths from leukaemia between the dose groups for the whole study population (calculated on the assumption that there was no excess risk of leukaemia associated with the radiation treatment). The estimated excess risk of leukaemia in the spondylitic patients according to the mean radiation dose to the bone marrow is given in table XIII and fig 2 . The greatest risk of leukaemia induction was in the group of patients with a mean marrow dose of 100 to 200 rads. At higher doses the risk appeared to be reduced. The data were not well fitted by a straight line constrained to give no excess risk at zero dose $(p=0.03$; see table $X V)$; indeed, the data were better fitted by a line which assumed that the excess risk was constant in all dose groups (likelihood ratio test $(1 \mathrm{df})=5 \cdot 17 ; \mathrm{p}<0.05)$.

When possible the clinical notes of each patient with leukaemia were reviewed. In the Appendix the cell types of the "preferred" diagnoses ${ }^{1}$ are given. It was not possible to calculate the expected numbers of leukaemias of each type from mortality rates in England and Wales, because deaths from leukaemia were not classified by cell type nationally for most of the study period. Nevertheless, chronic lymphatic leukaemia was diagnosed in none of the 28 patients for whom leukaemia was recorded as the underlying cause of death. The deaths of all three patients who had chronic lymphatic leukaemia recorded on their death certificates were certified as due to nonmalignant diseases. Patients who developed chronic lymphatic leukaemia received, on average, a lower radiation dose to their bone marrow than did patients who developed other forms of leukaemia (mean bone marrow doses were chronic lymphoblastic leukaemia (3 patients); 144 rads; acute lymphoblastic leukaemia (5 patients): 221 rads; myeloid

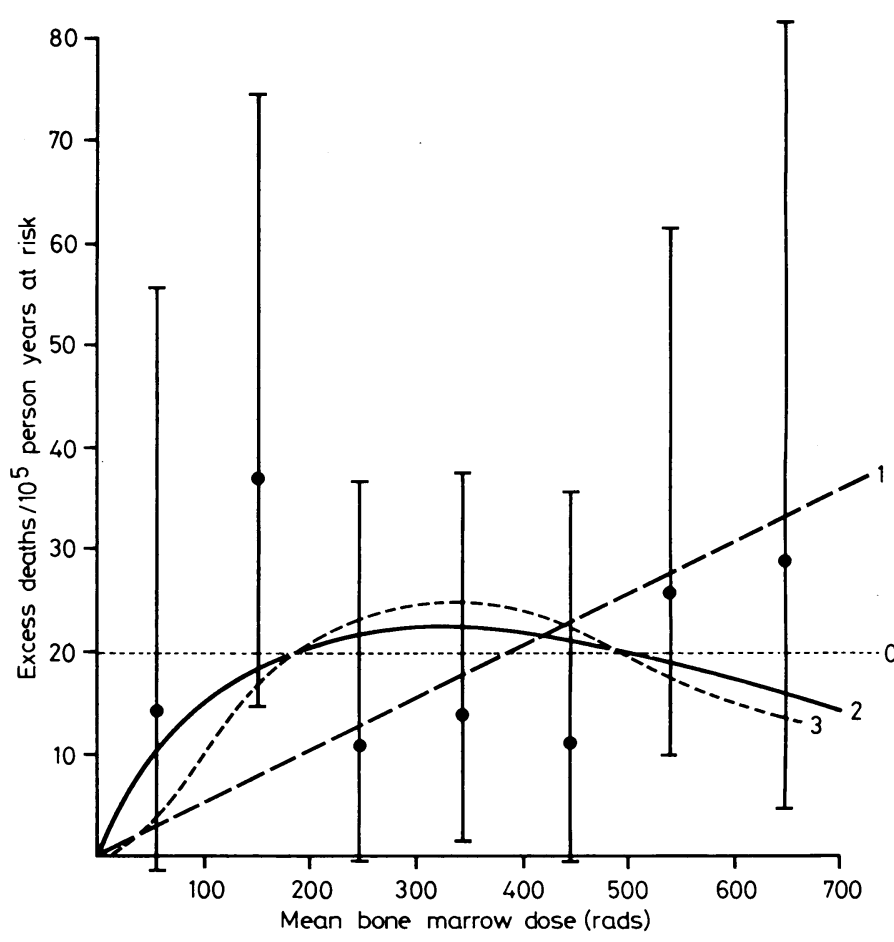

FIG 2-Excess death rate from leukaemia more than 18 months (on average) after first treatment according to mean bone marrow radiation dose. Curves are based on following models: (0) $\mathrm{ER}=\mathrm{b}:$ (1) $\mathrm{ER}=\mathrm{bD}$; (2) $\mathrm{ER}=\mathrm{bDe} \mathrm{e}^{-\lambda \mathrm{D} \text {; }}$ and (3) $E R=b D^{2} e^{-\lambda D}$, where $E R$ is the excess leukaemia death rate, $D$ is the mean bone marrow dose, and $b$ and $\lambda$ are constants that were estimated for each model by the method of maximum likelihood (the estimated values are given in table XV for models 1,2 , and 3 and in the text for model 0 . 
dose to the mediastinal lymph nodes on the assumption that such tumours originate from this site.

As the only information available was the estimated radiation dose and the excess cancer risk for each site we expressed the excess risk in terms of the excess deaths per million years at risk per rad assuming a linear relationship between dose and excess risk. We have, however, no data that enable us to test the reasonableness of this assumption. The results are very similar to the estimates based on our data that have been derived by J T Lyman and J I Fabrikant (paper delivered at 6th International Congress of Radiation Research, Tokyo, 1979).

\section{Discussion}

Previous analyses of the mortality among patients with ankylosing spondylitis treated with $x$ rays $^{12}$ included deaths among patients who had received more than one course of $x$ ray treatment. This made it difficult to measure the size of changes associated with either the dose of radiation or the length of time since the radiation exposure because it was not obvious how to take into account the effects of the second or subsequent course of radiation on the death rates. We avoided the problem in this exposure rather than to the underlying disease. They do not support the suggestion that radiation exposure produces a nonspecific "aging" effect, affecting death rates from causes other than cancer (except possibly aplastic anaemia). We have discussed elsewhere the increase in mortality associated with spondylitis itself ${ }^{10}$ and confine the discussion here to deaths from leukaemia and other cancers.

\section{LEUKAEMIA}

There is overwhelming evidence that ionising radiations are leukaemogenic in man. ${ }^{13}$ What is less certain is the way in which the risk of developing leukaemia varies with time after radiation exposure, the dose of radiation, and the age and other characteristics of the person irradiated. In this study the risk of dying of leukaemia was raised by the second year after treatment and the greatest risk was 3 to 5 years after treatment. Subsequently both the ratio of observed to expected deaths and the excess death rate declined significantly. Only five deaths occurred from 12 to 17 years after first treatment ( 1.9 were expected), and there was only

TABLE XIV-Excess death rates for cancers of selected sites related to estimated organ radiation dose

\begin{tabular}{|c|c|c|c|c|c|c|c|c|c|c|c|}
\hline \multirow{2}{*}{\multicolumn{2}{|c|}{ Organ (site) }} & & & & \multirow{2}{*}{$\begin{array}{c}\text { Mean } \\
\text { dose } \\
\text { (rads)* }\end{array}$} & \multicolumn{3}{|c|}{$\begin{array}{c}\text { Deaths } 3 \text { or more } \ddagger \text { years } \\
\text { after irradiation }\end{array}$} & \multicolumn{3}{|c|}{$\begin{array}{c}\text { Deaths } 9 \text { or more years } \\
\text { after irradiation }\end{array}$} \\
\hline & & & & & & Observed & Expected & $\begin{array}{l}\text { Excess deaths } \\
/ 10^{6} / \text { year } / \mathrm{rad}\end{array}$ & Observed & Expected & $\begin{array}{l}\text { Excess deaths } \\
/ 10^{6} / \text { year/rad }\end{array}$ \\
\hline \multicolumn{8}{|c|}{ Mediastinal lymph nodes (lymphomas } & $(0.09,0.50) \S$ & & & $(0.10,0.75)$ \\
\hline Oesophagus & & $\ldots$ & $\ldots$ & .. & 306 & 10 & 4.90 & $(0.02,0.39)$ & 8 & 3.62 & $(0.02,0.61)$ \\
\hline Stomach & . & . & . & . & $\begin{array}{c}67^{\dagger} \\
89 \\
250\end{array}$ & 39 & $29 \cdot 12$ & $\begin{array}{ll}1.45 & (0.03,3.21) \\
1.09 & (0.02,2.42) \\
0.39 & (0.01,0.86)\end{array}$ & 31 & $20 \cdot 03$ & $\begin{array}{ll}2.82 & (0.62,5.61) \\
2.12 & (0.47,4 \cdot 22) \\
0.76 & (0.17,1.50)\end{array}$ \\
\hline Colon & .. & . & $\ldots$ & .. & 57 & 22 & $14 \cdot 78$ & $1.25 \quad(0.02,2.88)$ & 16 & $10 \cdot 38$ & $1 \cdot 70(-0 \cdot 10,4 \cdot 21)$ \\
\hline Pancreas & $\therefore$ & . & . & . & 90 & 13 & $8 \cdot 48$ & $0.50(-0.09,1.34)$ & 10 & $6 \cdot 35$ & $0.70(-0.18,2.03)$ \\
\hline Bronchus & $\therefore$ & $\ldots$ & . & . & 197 & 111 & $78 \cdot 68$ & $1.62(0.78,2.57)$ & 88 & $58 \cdot 90$ & $2.55 \quad(1.25,4.04)$ \\
\hline Vertebral bc & one $\quad \cdots$ & $\ldots$ & . & .. & 505 & 3 & 0.96 & $(0.00,0.13)$ & 3 & 0.55 & $(0.01,0.25)$ \\
\hline Spinal cord & and nerves & . & . & $\ldots$ & 698 & 4 & 0.51 & $0.05 \quad(0.01,0.12)$ & 2 & $0 \cdot 37$ & $(0.00,0.15)$ \\
\hline Kidney & $\ldots \quad \ldots$ & . & .. & .. & 46 & 7 & 3.59 & $0.73(-0.07,2.05)$ & 7 & $2 \cdot 61$ & $1.65 \quad(0.25,3.95)$ \\
\hline Bladder & $\ldots$ & . & . & .. & 31 & 11 & $6 \cdot 82$ & $1.33(-0.21,3.62)$ & 8 & $5 \cdot 07$ & $1.63(-0.61,5.21)$ \\
\hline
\end{tabular}

* As given in BEIR report.

+ BEIR $^{9}$ gives two estimates of the dose to the stomach based on different assumptions: 67 and 89 rads.

$\ddagger$ On average $2 ! 2$ years or more, see footnote to table IV. $\$ 90 \%$, confidence intervals are shown in parentheses.

analysis by excluding observations on patients more than 18 months after a second course. Even with this restriction the total number of deaths observed from all causes was $66 \%$ greater than would have been expected if the patients had had the same mortality as the population of England and Wales, and this increased risk of death persisted more than 20 years after first treatment (table IV).

A smaller group of patients with ankylosing spondylitis, who were diagnosed during the same period as patients in this series but who were not treaed with $x$ rays also had mortality rates which were about $60 \%$ greater than expected from national rates, and this strongly suggests that the $x$ ray treatment is responsible for inducing a relatively small proportion of the total excess of deaths in irradiated patients. ${ }^{1012}$ When deaths were examined separately by cause, no deaths from leukaemia were observed in patients who had not been irradiated and the number of deaths from cancers of sites that would have been classed as "heavily irradiated" in the patients treated with $x$ rays was close to the number expected. In contrast the ratio of the number of deaths from non-neoplastic conditions to the number expected (1.8:1) was close to that in the irradiated patients (table III: $1 \cdot 7: 1$ ). These findings must be interpreted with caution as the number of patients who had not been treated with $x$ rays was comparatively small (1021) and the percentage of those patients who were not completely traced to the end of the study period $(16 \%)$ was undesirably high. The results indicate, however, that the excess of deaths from leukaemia and cancers of the heavily irradiated sites among irradiated patients are likely to be due to the radiation one death from leukaemia 18 or more years after first treatment when one was expected (table IV). When the excess risk of leukaemia was standardised for age at first treatment the results were barely changed (table XII). Our data were too sparse to rule out the possibility that no excess risk remains beyond 18 years after exposure, but most of the radiation-induced leukaemias have probably already occurred. A similar finding has been reported for the survivors of the atomic bomb explosions. The excess risk of leukaemia was considerably reduced by 20 years after the explosions but some remained beyond this period. ${ }^{11} 14$

Two or more years after treatment the overall excess mortality from leukaemia was $19 \cdot 6 / 100000$ person years at risk, or $24 \cdot 5 / 100000$ person years at risk when we included the seven patients with leukaemia whose primary cause of death was not given as leukaemia on their death certificates.

To use these rates to estimate the leukaemogenic effects of radiation on populations exposed to different levels of radiation it is necessary to relate the excess risk to the estimated mean bone marrow dose and, as illustrated by fig 2 , the assumption of a linear dose-response relationship over the whole range of doses received by the spondylitic patients may not be justified.

Patients irradiated for the treatment of cervical cancer do not appear to have an increased risk of leukaemia ${ }^{15}{ }^{16}$ whereas women given a radiation-induced menopause have shown an increased death rate from leukaemia ${ }^{17}$ even though their bone marrow is likely to have received a much smaller dose of radiation. These observations are incompatible with a linear dose-response relationship for leukaemia induction by radiation. ${ }^{15} 18$ It has been 
suggested that patients with cancer of the cervix are not at increased risk of leukaemia because the radiation treatment is given in such a way that some of the bone marrow receives a very high dose of radiation, sufficient to sterilise the marrow cells, and that the dose to the rest of the marrow falls off rapidly with increasing distance from the cervix. Thus, most of the marrow cells receive either a radiation dose which is so damaging that they cannot survive a division or a dose which is so small that it confers too small a risk of leukaemia to be detectable in epidemiological studies.

Many of the spondylitic patients in our study received an estimated mean marrow dose of over 300 rads. As only part of the marrow is irradiated in the treatment of spondylitis, the dose to cells directly in the radiation field may have been higher than the mean dose by a factor of two or more (the spinal marrow constitutes about $40 \%$ of the total bone marrow). Thus many of the cells directly in the line of the radiation may have received a dose large enough to sterilise them and thus render them incapable of becoming leukaemic.

Mathematical models relating the risk of leukaemia to radiation dose that take account of the cell-sterilising effect of radiation fit well with experimental data on radiation-induced myeloid leukaemias in mice, ${ }^{19}$ and $M o l e^{20}$ has fitted models of this nature to data from human studies. We have fitted some of these models to the data on leukaemia shown in table XIII, and the results are summarised in table XV and fig 2 . Clearly the data

TABLE XV-Models relating the excess risk of leukaemia to radiation dose

\begin{tabular}{|c|c|c|c|c|}
\hline \multirow[b]{2}{*}{ Model for excess risk* } & \multicolumn{2}{|c|}{ Maximum likelihood estimates } & \multicolumn{2}{|c|}{ Goodness of fit } \\
\hline & $b\left(\times 10^{6}\right)$ & $\lambda\left(\times 10^{2}\right)$ & $\chi^{2}(\mathrm{df})$ & $\mathbf{p}$ \\
\hline $\begin{array}{l}\text { (1) } b D \\
\text { (2) } b \mathrm{be}^{-\lambda \mathrm{D}}\end{array}$ & $\begin{array}{l}0.52(0.31,0.86) \dagger \\
2.02(0.47,6.08)\end{array}$ & 0.33 & $\begin{array}{l}13 \cdot 78(6) \\
6 \cdot 31(5)\end{array}$ & $\begin{array}{l}0 \cdot 03 \\
0 \cdot 28\end{array}$ \\
\hline (3) $b D^{2} e^{-\lambda D}$ & $0.0182(0.0041,0.0808)$ & $0 \cdot 63$ & $9 \cdot 67(5)$ & $0 \cdot 09$ \\
\hline
\end{tabular}

* $\mathrm{b}$ and $\lambda$ are constants to be estimated and $\mathrm{D}=$ mean marrow dose (in rads)

+ Approximate $90 \%$ confidence intervals are shown in parentheses.

are not well fitted by a model that assumes a simple linear relationship between the excess risk and radiation dose with zero excess risk in the absence of radiation $(p=0.03)$. If in addition, however, cell sterilisation is assumed to be of a simple exponential form with dose, the linear model provides a reasonable fit to the data (fig $2 ; p=0 \cdot 28$ ). A model in which it is assumed that leukaemia induction is related to the square of dose (model 3 , table XV) fits the data less well (fig $2 ; p=0.09$ ). The estimate of the leukamogenic effect of low doses of radiation obtained from model 2 is about 2.0 leukaemia deaths/million persons $/ \mathrm{rad} /$ year and this is similar to the estimate of 2.4 deaths/million persons/rad/year ( $90 \%$ confidence limits $1 \cdot 1$ to $4 \cdot 3$ ) obtained when a simple linear dose-response relationship (with no allowance for cell sterilisation) is fitted to those receiving a mean bone marrow dose of 200 rads or less. This estimated leukaemia induction rate is similar to that derived from study of the survivors of the atomic bomb explosions at Hiroshima and Nagasaki. Beebe et al ${ }^{21}$ have estimated the excess risk of leukaemia to be $1.9 / \mathrm{million} / \mathrm{year} / \mathrm{rad}$ for the two cities combined, assuming a relative biological effectiveness of unity between gamma and neutron radiation. A recent reanalysis of these data using a linear regression equation in which there were separate terms for gamma and neutron radiation derived an estimate for the effect of gamma radiation alone on the incidence of leukaemia of $2 \cdot 2 / \mathrm{million} / \mathrm{year} / \mathrm{rad} .^{9}$ (New evidence ${ }^{22}$ strongly suggests that the radiation dose estimates made for the atomic bomb survivors are incorrect, particularly with reference to the doses in Hiroshima, where the neutron doses were much less than was previously thought while the gamma doses were considerably higher. The dose-response estimates for leukaemia and other tumours will therefore probably need to be reassessed although it is unlikely that the effects per rad will prove to be $\frac{\text { W }}{7}$ much greater than those estimated previously.) Most of the survivors of the atomic bomb explosions received estimated $\varrho$ whole-body doses of radiation of less than 300 rads, and a linear relationship between leukaemia risk and dose fits quite $\frac{\varrho}{\bar{F}}$ well, though some authors have preferred to use a linearquadratic model.

The validity of the models we have fitted, in which an expo- os nential function is incorporated to allow for cell sterilisation, is $\varrho$ questionable, as only part of the bone marrow is irradiated and $\vec{\Rightarrow}$ the fraction varies from patient to patient. (For example, we $\stackrel{9}{\rightarrow}$ obtain a different estimate of the sterilising effect of radiation than has been obtained in in-vitro studies. On model 2 the value $\underline{\overline{\underline{T}}}$ of $\lambda$ obtained indicates that a mean radiation dose of 210 rads to $\frac{D}{\vec{D}}$ the bone marrow (equivalent to an actual dose to irradiated $\stackrel{\square}{\Omega}$ marrow of about 400 rads) will sterilise $50 \%$ of cells, whereas $ڤ$ in-vitro studies have suggested that a dose of less than 100 rads $\vec{\circ}$ will sterilise $50 \%$ of human marrow cells. ${ }^{23}$ We also took no account of the time over which the treatment course was $\vec{\omega}$ administered. This period may have been a month or more, and $\stackrel{\mathscr{D}}{\mathrm{D}}$ the consequent fractionation of the total radiation dose would $\frac{5}{3}$ probably have had an effect on cell survival different from that which would have occurred if the same dose had been given $\stackrel{\infty}{+}$ without fractionation. ${ }^{23}$ ) Thus two patients may be recorded as having received the same mean bone marrow dose even though $\vec{A}$ one received a higher dose to a smaller volume of marrow than the other. The form of our dose-response relationship nevertheless suggests that it would be appropriate to allow for the 0 sterilisation effect of radiation on cells when constructing models to predict the effects of low doses of radiation based on data $\vec{\omega}$ collected at higher doses.

Previous analyses of the relationship between radiation dose $\frac{\mathbb{O}}{1}$ and the risk of developing leukaemia in the spondylitic patients have suggested a linear dose-response relationship for mean spinal marrow doses of up to 2000 rads. $^{24}$ Those analyses $\vec{\varphi}$ included patients who had received more than one course of treatment, and the estimated doses from the different courses $\square$ were simply added. The effect of two or more courses of radiation may be greater than that of the same amount of radiation given in a single course. This may explain the apparent discrepancy between the present analysis based on patients receiving $\stackrel{\varnothing}{\varnothing}$ only one course of radiation and earlier ones.

If such an explanation is true the nature of the fractionation of $\overrightarrow{\overrightarrow{0}}$ the radiation treatment during a single course of treatment might $\frac{3}{2}$ be expected to affect the leukaemic risk. We sought to determine, therefore, whether the patients who developed leukaemia had been given their radiation treatment in a different way from those who did not develop the disease. For the 33 irradiated patients who developed leukaemia and for whom we had a detailed record of the original radiation treatment (all of those in the Appendix except for cases 1 (no radiation record) and 31 (bone $\delta$ marrow was not irradiated) four matched controls were selected $₹$ from among the 1 in 15 sample of all patients for whom detailed 은 radiotherapy records had been extracted. The sample was $N$ arranged in order of estimated bone marrow dose, and matched controls were chosen for each patient who died of leukaemia by selecting four patients of the same sex whose estimated dose was closest to that of the patient (two with higher doses and two with lower). For each patient and the matched controls information $\omega$ was extracted from the radiotherapy notes on the total duration of the first treatment course, the age at treatment, the year of treatment, and the number of occasions that the patients $\mathbb{D}$ attended for radiotherapy. The patients with leukaemia were found, on average, to have been treated at an older age than the $\frac{T}{0}$ controls and at a later date, though the latter difference was not $\stackrel{\mathrm{D}}{\mathbb{D}}$ statistically significant; but there were no significant differences $\frac{?}{8}$ in the length of the treatment or in the numbers of fractions into $\stackrel{\mathbb{2}}{2}$ which the radiotherapy was divided.

It is clearly a matter of some concern that our data show no 8 clear relationship between the excess risk of leukaemia and radiation dose. Although model 2 (table XV) provides a reasonable fit to the data, so would a wide variety of other models, including 
one which postulates a constant excess risk at all doses (including zero dose). Considered alone, a reasonable interpretation of this last finding would be that the excess risk of leukaemia is associated with ankylosing spondylitis itself rather than its treatment. We do not favour this view for two reasons. Firstly, we found no deaths from leukaemia among patients with ankylosing spondylitis who had not been treated with $x$ rays, ${ }^{12}$ and, although the follow-up was of relatively few patients, this finding was significantly different from that observed in the irradiated series. Secondly, the excess of deaths from leukaemia after radiotherapy for spondylitis peaked three to five years after treatment and then declined, whereas a constant excess with time might have been expected had the leukaemias been associated with the disease itself. Therefore the leukaemia excess is probably radiation induced, and models should be required to accommodate zero excess with zero doses. The use of our findings to estimate the leukaemogenic effects of the low doses of radiation must clearly depend on the choice of model to be used for extrapolation.

The risk of radiation-induced leukaemia in adult life increases with the age of patients at irradiation. ${ }^{25}$ This effect was just as clear when the analysis was confined to subjects receiving only a single course of radiation (table $\mathrm{XI}$ ). The effect is unlikely to be due to a variation in the radiation doses received by patients of different ages, as the mean age at treatment of patients receiving different doses of radiation showed little variation (table XIII) and no consistent trend. The number of deaths from leukaemia was four or five times the number of deaths expected in each age at first treatment group. This strongly suggests that radiation interacts with other factors which induce leukaemia in a multiplicative way. In the atomic bomb survivors the highest risk of leukaemia induction (measured as the ratio of observed to expected deaths) was seen in those aged less than 10 years at the time of exposure. At older ages the ratio remained roughly constant with a suggestion of an increased ratio among those aged 50 years or more at exposure. ${ }^{21}$ Our data suggest that in adult life susceptibility to radiation-induced leukaemia increases with age at exposure but do not test the hypothesis that young children are particularly susceptible, as none of the spondylitic patients were treated for their disease in childhood.

Ichimaru et $a l^{11}$ have suggested that among the atomic bomb survivors the interval between irradiation and the development of leukaemia increased in proportion to age at the time of exposure. We found no evidence of such an effect in our data, though the age span of the spondylitic patients at their first treatment was considerably less than that of the ages at exposure of the atomic bomb survivors. Among those spondylitics treated at less than 25 years, $25-34,35-44,45-54$ and 55 or more years the average times between first treatment and death from leukaemia were, respectively, $5 \cdot 0,4 \cdot 9,8 \cdot 5,11 \cdot 0$, and $5 \cdot 7$ years, these means being based on $1,7,8,8$, and 4 deaths from leukaemia, respectively. (When the four other deaths with leukaemia are included (excluding the three deaths with chronic lymphatic leukaemia (see Appendix), which are unlikely to have been radiation induced) the means were, respectively, 5.0, 5.5, 8.5, $10 \cdot 4$, and $4 \cdot 8$ years based on $1,8,8,9$, and 6 deaths.)

In comparing our results with those from other studies it should be noted that after first treatment patients have been withdrawn from our study at a faster rate than might generally be expected. Not only do spondylitics have a considerably raised death rate from other causes, unassociated with the radiation exposure, but for the present analysis they were also withdrawn shortly after their second treatment, which a high proportion of patients received (table I).

The net result of these two effects was for the distribution of the number of person years at risk according to the time since first treatment to be weighted towards the first few years after treatment, when the risk of a radiation-induced leukaemia is relatively high. Thus the summary risk estimates given previously will be too high for estimating the possible effects of radiation exposure on other populations. We therefore applied the rates given in table XII (after standardisation for age at irradiation) to a standard population with the same age distribution as that of the spondylitics at the time of irradiation to derive estimates of the excess risk of leukaemia in the 20 years after exposure in the absence of other causes of death (we assumed that there was no excess risk of leukaemia in the first 18 months after exposure). We estimated that 318 deaths from leukaemia will be induced per 100000 persons irradiated-that is, $15 \cdot 9 / 100000$ per year.

\section{CANCERS OF LIGHTLY IRRADIATED SITES}

We classified body sites into those which were lightly or heavily irradiated taking into account the body areas to which radiation fields were usually applied in the treatment of spondylitis in the patients in this series. This was necessarily a rough division, as treatment practices varied considerably between centres, and some of the sites classed as lightly irradiated may not always have been excluded from the treatment fields. Furthermore, some of these sites probably received some radiation as scatter from treatment applied close by. Thus, although none of the individual sites shown in table VI was associated with a statistically significant increased risk of cancer, the excess of deaths over the expected numbers for cancers of the kidney and bladder may be due in part to radiation effects. The original treatment details were not available for most patients and thus the position of the radiation fields for those patients developing cancer could not be checked. Three or more years after first treatment there was an overall excess of deaths from cancers of lightly irradiated sites of about $20 \%$, but this increase was not statistically significant and was significantly less than the corresponding $50 \%$ excess of deaths from cancers of heavily irradiated sites (tables VII and VIII; $\chi^{2}(1 \mathrm{df})=2 \cdot 72$; $\mathrm{p}<0.05$ (one-sided)).

Estimates were given by the BEIR committee ${ }^{9}$ of the doses to the kidneys and the bladder and on the basis of these, we estimated that the excess risk of cancers of these sites three or more years after radiation were 0.7 and $1.3 / 10^{6} /$ persons $/$ year $/ \mathrm{rad}$ respectively (table XIV).

\section{CANCERS OF HEAVILY IRRADIATED SITES}

The ratios of observed to expected deaths three or more years aftẹr first treatment for cancers of sites classed as heavily irradiated showed some variation (table VII), but when CNS tumours were excluded (some of which may have been present at the time of first treatment) the variation was not statistically significant. Thus our data were compatible with the radiation risk being directly proportional to the expected death rate from cancer in the absence of radiation. As we also observed for leukaemia, this suggests that radiation interacts in a multiplicative way with other factors which induce cancer. Further evidence is provided by the observation that for patients first irradiated at different ages the subsequent risk of dying of cancer was approximately proportional to the expected cancer death rate in the absence of any radiation treatments (tables IX and X). Nevertheless, all our data related to adults, and children aged less than 10 years may be particularly sensitive to the carcinogenic effects of radiation. ${ }^{14}$

The ratio of observed to expected deaths from cancers of heavily irradiated sites declined after reaching a peak 9 to 11 years after first treatment (table IV). The excess death rate, however, remained roughly constant up to 20 years after first treatment (tables $\mathrm{V}$ and $\mathrm{X}$ ) and there was only slight evidence of a fall in this rate with longer periods of observation. Thus, while the risk of leukaemia to the spondylitics would seem to have diminished considerably, if not disappeared, by 20 years after first treatment, the risk of other radiation-induced cancers remains and it will be necessary to continue to follow-up the surviving patients to determine whether the excess cancer risk declines as the time since first treatment increases further. 
We thank the directors and staffs of the 87 British radiotherapy departments for their continued co-operation in this study. The task of tracing the members of the study population was undertaken by Angela Hewitt and Zoe Fotheringham and we much appreciate all their labours. Help with computing and data processing has been given by Mary Burgess, Carol Hermon, Kate Hughes, and Barbara Haffner. We were much saddened by the recent death of Professor Roy Ellis, with whom we had collaborated closely to estimate the radiation doses to the bone marrow. The study was funded initially by the Medical Research Council and is now supported by the Imperial Cancer Research Fund.

\section{Appendix}

Patients developing leukaemia after one course of treatment

\begin{tabular}{|c|c|c|c|c|c|c|}
\hline Case No & $\begin{array}{c}\text { Age at } \\
\text { treatment }\end{array}$ & Sex & $\begin{array}{c}\text { Year of } \\
\text { Treatment }\end{array}$ & Death & $\begin{array}{l}\text { Mean bone } \\
\text { marrow } \\
\text { dose (rads) }\end{array}$ & $\begin{array}{l}\text { Preferred } \\
\text { diagnosis } \ddagger\end{array}$ \\
\hline \multicolumn{7}{|c|}{ Leukaemia given on death certificate as underlying cause of death } \\
\hline 1 & 26 & $M$ & 50 & 52 & $(180)^{*}$ & AML \\
\hline 2 & 33 & $\mathrm{~F}$ & 45 & 47 & 102 & ALL \\
\hline 3 & 27 & $M$ & 53 & 55 & 477 & $\mathrm{AML}$ \\
\hline 4 & 53 & $\mathrm{M}$ & 50 & 54 & 376 & ML \\
\hline 5 & 27 & M & 48 & 52 & 294 & $A M L$ \\
\hline 6 & 52 & $\mathrm{M}$ & 52 & 56 & 115 & AML \\
\hline 7 & 42 & $M$ & 52 & 56 & 150 & AML \\
\hline 8 & 41 & M & 53 & 57 & 587 & $\mathrm{AML}$ \\
\hline 9 & 35 & $\mathrm{M}$ & 49 & 54 & 711 & AML \\
\hline 10 & 65 & M & 50 & 55 & 561 & AML \\
\hline 11 & 58 & $M$ & 46 & 51 & 432 & $\mathrm{AML}$ \\
\hline 12 & 21 & M & 53 & 58 & 183 & $\mathrm{AML}$ \\
\hline 13 & 63 & M & 47 & 52 & 433 & CML \\
\hline 14 & 53 & $\mathrm{~F}$ & 54 & 60 & 143 & AML \\
\hline 15 & 45 & M & 51 & 58 & 648 & $\mathrm{AL}$ \\
\hline 16 & 30 & M & 50 & 57 & 229 & ALL \\
\hline 17 & 31 & M & 47 & 54 & 823 & AML \\
\hline 18 & 44 & M & 49 & 57 & 370 & CML \\
\hline 19 & 76 & $\mathrm{~F}$ & 52 & 60 & 43 & $\mathrm{AL}$ \\
\hline 20 & 42 & M & 46 & 55 & 138 & $A M L$ \\
\hline 21 & 27 & M & 51 & 61 & 262 & ALL \\
\hline 22 & 40 & M & 50 & 61 & 368 & AML \\
\hline 23 & 43 & M & 54 & 66 & 546 & AML \\
\hline 24 & 39 & M & 50 & 65 & 563 & $\mathrm{AL}$ \\
\hline 25 & 45 & M & 53 & 68 & 30 & ALL \\
\hline 26 & 49 & M & 52 & 69 & 325 & $\mathrm{AL}$ \\
\hline 27 & 49 & M & 49 & 66 & 589 & CML \\
\hline 28 & 46 & M & 50 & 68 & 545 & AML \\
\hline \multicolumn{7}{|c|}{ Aplastic anaemia certified as cause of death but leukaemia preferred diagnosis } \\
\hline 29 & 69 & $\mathrm{M}$ & 51 & 53 & 539 & AML \\
\hline 30 & & $M$ & & & 530 & $\mathrm{AL}$ \\
\hline \multicolumn{7}{|c|}{ Leukaemia recorded on death certificate but not as underlying cause of death } \\
\hline 31 & 64 & $M$ & 53 & 58 & $0 \dagger$ & CLL \\
\hline 32 & 54 & $\mathrm{M}$ & 48 & 54 & 461 & AML \\
\hline 33 & 27 & M & 52 & 62 & 484 & ALL \\
\hline 34 & 48 & $\mathrm{~F}$ & 54 & 66 & 176 & CLL \\
\hline 35 & 36 & $M$ & 52 & 68 & 254 & CLL \\
\hline
\end{tabular}

* Estimated from mean spinal dose given in Court Brown and Doll, ${ }^{1}$ see text. Knees only irradiated.

AML = acute myeloid leukaemia; $\mathrm{CML}=$ chronic myeloid leukaemia; $\mathrm{ML}=$ ; $\mathrm{ALL}=$ acute lymphoblastic leukaemia; $\mathrm{CLL}=$ chronic lymphoblastic leukaemia; $\mathrm{AL}=$ acute leukaemia.

\section{References}

${ }^{1}$ Court Brown WM, Doll R. Leukaemia and aplastic anaemia in patients irradiated for ankylosing spondylitis. London: HMSO, 1957.

2 Court Brown WM, Doll R. Mortality from cancer and other causes after radiotherapy for ankylosing spondylitis. Br Med $\mathcal{f} 1965 ; 2: 1327-32$.

3 World Health Organisation. Manual of the international statistical classification of disease, injuries and causes of death: seventh revision. Geneva: World Health Organisation, 1957.

${ }^{4}$ Case RAM, Coghill C, Davis JM, Harley JL, Hytten CA, Pearson JT, Willard SR, Alderson MR. Serial mortality tables: neoplastic disease, 1, England and Wales 1911-1970. London: Division of Epidemiology, Institute of Cancer Research, 1976.

5 Office of Population Censuses and Surveys. Cancer Mortality. England and Wales 1911-1970. London: HMSO, 1975.

${ }^{6}$ Mantel N. Chi-square tests with one degree of freedom: extensions of the Mantel-Haenszel procedure. F Amer Stat Assoc 1963;58:690-700.

${ }^{7}$ Ellis RE, Healy MJR, Shleien B, Tucker T. A system for estimation of mean active bone marrow dose. Washington, DC: Bureau of Radiological Health, 1975. (DHEW Pub (FDA) 76-8015.)

${ }^{8}$ Rosenstein M. Organ doses in diagnostic radiology. Washington, DC: US Government Printing Office, 1976. (HEW Publication (FDA) 76-8030)

9 Advisory Committee on the Biological Effects of Ionising Radiations. The effects on populations of exposure to low levels of ionising radiation. Washington DC: National Research Council, National Academy Press, 1980.

9a Advisory Committee on the Biology Effects of Ionising Radiations. The effects on populations of exposure to low levels of ionising radiations. Washington, DC: National Research Council, National Academy Press, 1972.
${ }^{10}$ Radford EP, Doll R, Smith PG. Mortality among patients with ankylosing w spondylitis not given $x$-ray therapy. $N$ Engl f Med 1977;297:572-6.

11 Ichimaru M, Ichimaru T, Belsky JL. Incidence of leukaemia in atomic bomb survivors belonging to a fixed cohort in Hiroshima and Nagasaki, 1950-71. 7 Radiat Res 1978;19:262-82.

12 Smith PG, Doll R, Radford EP. Cancer mortality among patients with $\widehat{\Omega}$ ankylosing spondylitis not given $x$-ray therapy. $B r f$ Radiol $1977 ; 50$ : $\bar{J}$ 728-34.

${ }^{13}$ United Nations Scientific Committee on the Effects of Atomic Radiation. 㣽 Sources and effects of ionising radiation. New York: United Nations, 1977. \&

14 Jablon S, Kato H. Studies of the mortality of A-bomb survivors 5 . @ Radiation dose and mortality 1950-1970. Radiat Res 1972;50: " 649-98.

${ }^{15}$ Hutchison GB. Leukaemia in patients with cancer of the cervix treated with $\stackrel{\oplus}{\rightarrow}$ radiation. A report covering the first 5 years of an international study. $\mathcal{F}$ 음 Nat Ca Inst 1968;40:951-82.

${ }^{16}$ Boice JD, Hutchison GB. Leukaemia following radiotherapy for cervical $\overline{\bar{\omega}}$ cancer. 10 year follow-up of an international study. F Nat Ca Inst 1980; 65:115-29.

17 Smith PG. Leukaemia and other cancers following radiation treatment of pelvic disease. Cancer 1977;39:1901-5.

${ }^{18}$ Mole RH. Late effects of radiation : carcinogenesis. Br Med Bull 1973;29: $\vec{\circ}$ $78-83$

19 Major IR, Mole RH. Myeloid leukaemia in $x$-ray irradiated CBA mice. $\vec{\omega}$ Nature $1978 ; 272: 455-6$.

20 Mole RH. Ionising radiation as a carcinogen: practical questions and academic pursuits. Br $\mathcal{F}$ Radiol 1975;48:157-69.

${ }^{21}$ Beebe GW, Kato H, Land CE. Studies of the mortality of A-bomb N survivors: 6. Mortality and radiation dose, 1950-1974. Radiat Res 1978; $75: 136-201$

22 Loewe WE, Mendelsohn E. Revised dose estimates at Hiroshima and $\omega$ Nagasaki. Health Physics 1981 ;41:663-6.

23 Senn JS, McCulloch EA. Radiation sensitivity of human bone marrow cells measured by a cell culture method. Blood 1970;35:56-60.

${ }^{24}$ Doll R. The carcinogenic risk of radiation human leukaemia. Acta Union Internationalis Contra Cancrum 1960;16:418-21.

${ }^{25}$ Doll R. Cancer and aging: the epidemiological evidence. In: 10th Inter- $\vec{\omega}$ national Cancer Congress. Oncology Year Book 1970. Chicago: Medical Publishing Inc, 1970.

ONE HUNDRED YEARS AGO We have been favoured with information as to the medical history of the great naturalist, which will be read with much interest. Under the domination of a manysided, sensitive, and highly strung nervous system, the health of the late Charles Darwin was always delicate, and often seriously impaired. For many years, he was a sufferer from catarrhal dyspepsia; later, he suffered from various irregular manifestations of a gouty constitution, $\overrightarrow{\overrightarrow{0}}$ such as eczema, vaso-motor nerve-storms, vertigo, and other disorders 3 of sensation. Nevertheless, by means of great care in diet, exercise, $\vec{P}$ and regularity of sleep, he managed to keep himself in sufficiently good order for almost continual work of the highest kind. A year ago, he became subject to attacks of palpitation, with irregularity of the heart's action, occasionally accompanied by pain in the chest, spreading to the arms. A few months since, it was found that the heart and $\overline{7}$ greater blood-vessels were degenerating. The anginal attacks became more frequent, and signs of heart-failure more serious; and it was, $\delta$ as we understand, in one of these attacks that our greatest naturalist 3 expired. There are two common errors concerning Charles Darwin: 은 one is, that that illustrious man was a professor, whilst in fact he never held any chair or fulfilled any educational duties that would $\mathrm{N}$ entitle him to be so called; the second is the prevalent opinion that, $D$ in pursuit of the study of his great theory, he worked from morning to night. The truth is, that the delicate state of his health rendered $\mathrm{N}$ him incapable of prolonged thought for more than about three hours $\mathrm{N}$ daily. His success was due to the fact that he concentrated all his $\omega$ powers of thought on one subject, so that the yearly sum of the very few hours devoted on each day to such thought amounted to the high display of mental energy, the result of which is demonstrated by $\frac{\tau}{\mathbb{D}}$ his works, and by the great influence they have exercised on modern science and philosophy. More than one daily paper has compared 0 Darwin to White, of Selborne fame; but they only resembled each $\overline{0}$ other in being genial and scholarly gentlemen, living in the country, $\overrightarrow{\mathbb{D}}$ and saved from the disadvantages of constant interruption to thought $\frac{\overrightarrow{\mathbb{D}}}{\mathrm{Q}}$ by deficient worldly means. The author of the Natural History of $\varrho$ Selborne was not a profound thinker on deep biological questions, but rather an active observer of the habits and instincts of animals, which he described in that picturesque manner and a pleasant literary style which has justly made him a popular favourite. (British Medical Fournal, 1882.) 